\author{
Jakub Slawik ${ }^{1}$ \\ Chrześcijańska Akademia Teologiczna w Warszawie \\ ORCID: 0000-0001-7867-7714
}

\title{
Debora i Jael naprzeciwko Baraka i Sisery: o rolach genderowych w Księdze Sędziów 4,1-24²
}

\begin{abstract}
Abstrakt: Opowiadanie o Deborze z Sdz 4 zmusza do postawienia pytania o role genderowe jego bohaterek i bohaterów. Choć Debora i Jael przedstawione zostały w tradycyjnej roli żony, to praktycznie cała ich aktywność wykracza poza role przypisywane kobietom, gdyż zajmują "męskie" domeny aktywności społecznej: sądownictwo, prowadzenie bitwy, zgładzenie wroga. Obie postępują nie tylko mądrze, ale i zgodnie z Bożymi, zbawczymi zamiarami. Natomiast męscy bohaterowie zostają ośmieszeni i zhańbieni - umieszczeni w "nie-męskich" rolach jako niesamodzielni, bojaźliwi, domagający się opieki. Ostatecznie, mężczyzna-wódz Sisera zostaje podstępnie zabity ręką kobiety wyposażonej w sprzęty domowe. Opowiadanie to jest zatem genderową krytyką ról przypisywanych płciom, przede wszystkim kobietom.
\end{abstract}

Słowa kluczowe: Księga Sędziów 4, badania genderowe, role genderowe, Debora, Jael, hańba

1 Dr hab. Jakub Slawik jest profesorem w Chrześcijańskiej Akademii Teologicznej w Warszawie i luteraninem.

2 Artykuł powstał w dużej mierze w okresie ograniczeń w dostępie do zasobów bibliotecznych, a w szczególności zagranicznych, wynikających z pandemii koronawirusa. M.in. nie miałem dostępu do: Renate Jost, Gender, Sexualität und Macht in der Anthropologie des Richterbuches (Beiträge zur Wissenschaft vom Alten und Neuen Testament 164 [9,4]), Stuttgart 2006 czy David J. Zucker i Moshe Reiss, ,Subverting Sexuality: Manly Women; Womanly Men in Judges 4-5”, Biblical Theology Bulletin 45 (2015), 32-37. 


\section{Wprowadzenie}

$\mathrm{J}$ edną z podstawowych kategorii badawczych we współczesnej humanistyce jest tzw. gender ${ }^{3}$, czyli płeć kulturowa, w odróżnieniu od płci biologicznej. Gender to zespół cech przypisywanych kobiecości czy męskości w i przez kulturę ${ }^{4}$. Badania genderowe mają czynić widocznym gender, ujawnić wpływ i znaczenie tego, jak postrzegana jest kobiecość i męskość ${ }^{5}$. Nie wchodząc w spory pomiędzy esencjonalizmem i konstrukcjonizmem ani inne kwestie będące przedmiotem debat $\mathrm{w}$ dyskursie genderowym ${ }^{6}$, niniejszy artykuł jest próbą odczytania opowiadania z Sdz 4 uwzględniającego czy uwidaczniającego funkcjonowanie i działanie mężczyzn i kobiet. Najnowsze badania pokazują, że męskości i kobiecości nie należy pojmować jako binarnej opozycji, nie posiadają one ściśle zarysowanych granic ${ }^{7}$.

Można też uwzględnić zasadnicze składowe ludzkiej seksualności, wykraczające poza prostą dychotomię orientacji seksualnej i aktu: orientację seksualną, tożsamość genderową, rolę genderową oraz praktykę seksualną ${ }^{8}$. Orientacja seksualna odnosi się do preferencji

3 Na temat etymologii i pochodzenia tego słowa zob. C.R. Stimpson, G.H. Herdt (red.), Critical terms for the study of gender, 6-8.

4 Zob. A. Burzyńska, M. Markowski, Teorie literatury XX wieku, 443-451; M. Radkiewicz, „Co to są studia gender?”; C.R. Stimpson, G.H. Herdt (red.), Critical terms for the study of gender, 6, 450 .

5 Zob. M. Kimmel, Społeczeństwo genderowe, 29.

6 Do tego zob. A. Burzyńska, M. Markowski, Teorie literatury XX wieku, 441-454; M. Kimmel, Społeczeństwo genderowe czy R. Connel, Socjologia płci, podkreślająca błędność teorii esencjonalizmu (183-191). Mimo że w języku polskim pojawiło się sporo krytycznych publikacji (za przykład niech posłuży J. Jagiełło, D. Oko (red.), Gender - spojrzenie krytyczne, Kielce 2016), przedmiotem niniejszego opracowania nie są spory, dotyczące samej kategorii genderu, a jedynie męskość i kobiecość opisywanych postaci, ściślej role, w jakich działają męscy i żeńscy bohaterowie w jednym z opowiadań starotestamentowych.

7 Zob. M. Kimmel, Społeczeństwo genderowe; R. Connel, Socjologia płci, która mówi o względności relacji genderowych (34-49), choć z drugiej strony wzorce społeczne, struktury są niezwykle mocne (129-130).

$8 \mathrm{Za}$ M. Nissinen, Homoeroticism in the Biblical World, 9-14 (zob. I. Slawik, J. Slawik, „Homoseksualizm problemem Kościoła?”, 11-12). 
seksualnych, będących elementem osobistego doświadczenia człowieka. Tożsamość genderowa to ludzka samoidentyfikacja czy interpretacja samego siebie. Rola genderowa wynika natomiast z postrzegania kobiecości i męskości w społeczności, wywierającej - najczęściej mocną - presję na to, by pokrywała się z biologiczną płcią (orientacja nie musi odpowiadać roli społecznej). I w końcu praktyka seksualna nie ogranicza się bynajmniej do stosunku płciowego, ale obejmuje szeroko pojęty erotyzm (w tym np. fantazje). Może być ona mocniej determinowana normami społecznymi niż osobistą tożsamością. Płciowość człowieka warunkowana jest zatem przez czynniki biologiczne, społeczne oraz indywidualne przekonania i doświadczenia. Nie daje się ona też zredukować do binarnych opozycji natura/kultura, płeć/gender, biologia/otoczenie społeczne ${ }^{9}$. W interpretacji opowiadania w Sdz 4 można mówić w zasadzie jedynie o rolach genderowych, innymi słowy, społecznym wymiarze ludzkiej płciowości ${ }^{10}$. Niewiele czy zgoła nic nie będzie się dało powiedzieć o pozostałych wymiarach ludzkiej seksualności - może z wyjątkiem faktu, że bohaterki zostały wyraźnie określone jako kobiety i żony. Męskość jako uprzywilejowana nie została zaznaczona ${ }^{11}$. $\mathrm{Na}$ marginesie warto wspomnieć o tym, że role genderowe mogą korelować lub konkurować z innymi czynnikami, które mają wpływ na postrzeganie danych osób jako gorszych czy niżej sytuowanych. Gender jest tylko jedną z kategorii opisu różnic między ludźmi, obok takich jak rasa, klasa, pochodzenie etniczne, wiek, płeć itp. ${ }^{12}$

9 Zob. też C. Janssen, „Gender (NT)”. W płciowości splatają się najróżniejsze czynniki, a cały ten obszar w życiu społecznym R. Connel nazywa areną rozrodczości (zob. R. Connel, Socjologia płci, 117-125, zwł. 120).

10 Seksualność mająca niewątpliwie podłoże biologiczne nie jest jedynie ani w pierwszym rzędzie kwestią biologiczno-medyczną, lecz zagadnieniem społecznym (zob. przywołane powyżej R. Connel, Socjologia płci; M. Kimmel, Społeczeństwo genderowe czy C.R. Stimpson, G.H. Herdt (red.), Critical terms for the study of gender).

11 Doskonale przystają do tego obserwacje dotyczące iluzji neutralności genderowej i niewidzialności przywileju w M. Kimmel, Społeczeństwo genderowe, 23-28.

12 Mogą one zarówno uzupełniać badania genderowe (zob. A. Burzyńska, M. Markowski, Teorie literatury XX wieku, 453-545; C. Janssen, „Gender [NT]”, poświęcająca uwagę badaniom nad strukturami ucisku i marginalizacji i postulująca 
Opowiadanie w Sdz 4, które akcentuje znaczenie kobiet w wyobrażeniowej historii ${ }^{13}$ dawnego Izraela, $\mathrm{i}$ to $\mathrm{w}$ kontraście do postawy i działań mężczyzn, wydaje się szczególnie podatne na badania genderowe. Choć było ono już czytane czy analizowane w tej perspektywie $^{14}$, to wydaje się zasadne włączenie badań genderowych w analizę historyczno-krytyczną, która ma niejako kontrolować genderową lekturę ${ }^{15}$. W niniejszym artykule przeprowadza się analizę Sdz 4 za pomocą metody historyczno-krytycznej (choć niektóre niezwykle sporne zagadnienia nie mające większego znaczenia dla rozważanego zagadnienia, takie jak integralność literacka czy datowanie, jedynie zasygnalizowano) ${ }^{16} \mathrm{i}$ w powiązaniu z tzw. retoryką biblijną ${ }^{17}$. Ma ona być podstawą dla pytania o role genderowe, jakie pełnią czy w jakich ukazani zostali głowni bohaterowie. Choć nie poświęcono szczególnej uwagi krytyce integralności literackiej, to uwzględniono fakt, że przypuszczalnie starsze opowiadanie (w. 4-22) zostało umieszczone w szerszych ramach deuteronomistycznych całej Księgi Sędziów (w. 1-3.4b.23-24; 5,31b). Niniejsze opracowanie składa się zatem z tłumaczenia tekstu hebrajskiego (wraz z aparatem krytycznym), które nie chce być przekładem literackim, lecz odzwierciedlać budowę i treść opowiadania (stąd starano się zachować szyk z tekstu hebrajskiego), schematycznego przedstawienia konstrukcji opowiadania, posiadającego potrójnie klamrową budowę, jego analizy z podziałem na ramy („Opowiadanie w kontekście literackim”, uwzględniające również relację z Pieśnia Debory z Sdz 5) i pierwotne opowiadanie $\mathrm{Sdz} 4,4-22$. W analizie tej wskazywano od razu na role genderowe jej bohaterów. Całość zamyka omówienie ról genderowych, w których

tzw. hermeneutykę intersekcjonistyczną), jak i z nimi konkurować (zob. M. Kimmel, Społeczeństwo genderowe, 23).

13 Nie zajmuję się tutaj problematyką historyczności przekazów starotestamentowych, lecz jedynie tym, w jaki sposób interpretowano czy nadawano znaczenie rzeczywistym lub fikcyjnym zdarzeniom. Odnośnie problematyki starotestamentowego piśmiennictwa historycznego zob. M. Witte, „Geschichte / Geschichtsschreibung (AT)".

14 Zob. przywoływane w dalszych przypisach opracowania.

15 Zob. E. Blum, „Notwendigkeit und Grenzen historischer Exegese”, 35-40.

16 Zob. J. Slawik, Egzegeza Starego Testamentu i podana tam literatura.

17 Zob. R. Meynet, Wprowadzenie do hebrajskiej retoryki biblijnej. 
zostali ukazani bohaterowie: kobiety i mężczyźni. Ze względu na różne brzmienia nazw w przekładach posłużono się w przypadku rzadszych nazw i imion, tj. poza Deborą, Taborem i Jabinem, ich brzmieniem w tekście hebrajskim.

\section{Tłumaczenie}

1. I w dalszym ciągu Izraelici czynili zło w oczach JHWH, po tym jak Ehud zmarł.

2. Wtedy wydał ich JHWH w rękę Jabina, króla Kanaanu, który był królem w Chacor.

A dowódcą wojska jego był Sisera, który mieszkał

w Charoszet-Haggojim.

3. I wołali Izraelici o pomoc do JHWH, bo dziewięćset rydwanów ${ }^{18}$ żelaznych miał i on uciskał Izraelitów ${ }^{19}$ ciężko przez dwadzieścia lat.

4. Zaś Debora, kobieta, prorokini, żona Lappidota, ona była sędziną Izraela w tym cz asie.

5. I siadywała pod palmą ${ }^{20}$ Debory, pomiędzy Ramą ${ }^{21}$ i Betelem, w górach Efraima, i przychodzili do niej Izraelici na sąd.

6. A posłała i wezwała Baraka, syna Awinoama z Kedesz-Naftali, i powiedziała do niego:

Czy nie nakazał JHWH, Bóg Izraela:

18 Tłumaczę jako rzeczownik kolektywny (zob. $H A L)$.

19 W G i kilku Mss nie ma בְנֵ (zob. BHS i BHQ). Ponieważ w Sdz nieraz mowa jest o Izraelu, a nie Izraelitach (dosłownie „dzieciach Izraela”; 3,13; 6,6 itp.), krótsza lekcja mogłaby mieć pierwszeństwo. Jednak już w pierwszej części w. 3 pojawili się „synowie Izraela”, co uprawdopodobnia twierdzenie, że taka lekcja również w drugiej części wiersza jest pierwotna.

20 Zaskakująca wokalizacja to forma dialektowa od דָָר (zob. $H A L$ ) lub jest tendencyjna (od בשֶת; zob. HAHAT; czemu zaprzecza W. Groß, Richter, 266). Ta forma pojawia się jeszcze w niepewnym znaczeniu w Jr J0,5 (palma służąca jako straszydło na ptaki?).

21 Nazwa geograficzna z przedimkiem pojawia się w przypadku ograniczenia danego rodzaju do jednego przedmiotu (czyli ta konkretna Rama; por. הדיָּר , czyli Eufrat) - zob. Gesenius' Grammatik, § 126e; C. Brockelmann, Syntax, 19. 
Idż22 i pociagnij ${ }^{23}$ na górę Tabor,

$i$ weź ze sobą dziesięć tysięcy mężczyzn spośród Naftali-

czyków i spośród Zebulonitów;

7. a pociagne do ciebie nad potok Kiszon Siserę, dowódce wojska Jabina,

$i^{24}$ wozy jego i thum jego,

$i$ wydam go w recke twoja?

8. A odpowiedział jej Barak:

Jeśli pójdziesz ze mną, to pójdę,

jeśli nie pójdziesz ze mną, nie pójdę ${ }^{25}$.

9. I powiedziała:

Oczywiście pójdę z tobą,

tylko że ${ }^{26}$ nie zyskasz chwały na drodze, którą idziesz, gdyż w rękę kobiety wyda JHWH Siserę.

I wstała Debora, i poszła z Barakiem do Kedesz.

10. Wtedy zwołał Barak Zebulona i Naftaliego do Kedesz, i wspięło się pieszo dziesięć tysięcy ${ }^{27}$ mężczyzn, i wspięła się z nim Debora.

22 W G odczytano spółgłoski jako бoı. (,tobie”), czyli jako dopełnienie dalsze czasownika צוה (zob. BHQ). Lekcja TM z nakazem wymarszu jest z pewnością lepsza (zob. T.C. Butler, Judges).

23 משך oznacza ,zajmować pozycję”, ,ciągnąć na bitwę” (zob. HAHAT); ponownie występuje na początku w. 7 .

${ }^{24} \mathrm{Z}$ powodu spójnika lepiej rozumieć את jako notę acc. (zob. tłumaczenie w W. Groß, Richter, 255), a nie przyimkowo (jak w W. Hertzberg, Die Bücher Josua, Richter, Ruth, 170; T.C. Butler, Judges).

25 G znacząco rozszerza tekst: „,bo nie znam dnia, w którym anioł Pana sprawi,

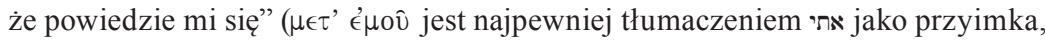
a nie noty acc.) - por. w. 14 (zob. BHQ). Wydaje się, że jest to glosa wyjaśniająca warunek Baraka (zob. BHS; H.-D. Neef, „Der Sieg Debora”, 32) czy raczej mająca go usprawiedliwić.

26 Do tłumaczenia אֶפֵ zob. HAL i W. Groß, Richter, 271 (spójnik restryktywny). Rozszerzający wariant $\mathrm{G}$ to stylistyczne uzupełnienie (zob. $B H S, B H Q$ i H.-D. Neef, „Der Sieg Debora”, 32; T.C. Butler, Judges; W. Groß, Richter, 257).

27 Masoreckie sebirin w kilku Mss (zob. BHS) wskazuje na to, że forma st. cs. liczebnika jest tak samo poprawna jak st. abs. w w. 6.14 (do sebirin zob. E. Tov, Der Text der Hebräischen Bibel, 51-52). 
11. Zaś Chewer, Kenita, oddzielił się do Kaina, od synów Chowawa, teścia ${ }^{28}$ Mojżesza, i rozbił namiot swój aż pod terebintem w Caa(na)nim ${ }^{29}$, który jest koło Kedesz.

12. I donieśli Siserze, że wspiął się Barak, syn Awinoama, na ${ }^{30}$ górę Tabor.

13. Wtedy zwołał Sisera wszystkie rydwany swoje, dziewięćset rydwanów żelaznych, i cały lud, który był z nim z Charoszet-Haggojim, do wadi Kiszon.

14. I powiedziała Debora do Baraka:

Wstań, bo to jest dzień, w którym wydał JHWH Siserę w rękę twoją!

Czyż nie JHWH wyszedł ${ }^{31}$ przed tobą?

I zszedł Barak z góry Tabor i dziesięć tysięcy mężczyzn za nim.

15. Wtedy wywołał JHWH zamieszanie u Sisery i wszystkich rydwanów, i całego wojska ${ }^{32}$ ostrzem miecza ${ }^{33}$ przed Barakiem,

${ }^{28}$ W BHS proponuje się zmianę wokalizacji, by otrzymać słowo „szwagier”, w celu ujednolicenia z Lb 10,29, według którego Chowaw jest synem teścia Mojżesza Reuela.

${ }^{29}$ Q dodaje ม (dodatkową sylabę), wiążąc tą nazwę z Joz 19,33 (granice terytorium Naftaliego) - zob. BHS; $B H Q$ i W. Groß, Richter, 257. Do lekcji G zob. $B H Q$ i W. Groß.

${ }^{30}$ Kilka Mss dodaje b (zob. BHS), który gramatycznie jest zbędny. Z tego samego powodu Vrs (zob. $B H Q$ ) nie poświadczają w rzeczywistości żadnego innego wariantu tekstowego.

31 W G odczytano czasownik jako impf. (w T oddano go w ptp.) - zob. $B H Q$.

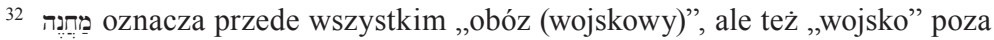
obozem - zob. HAL.

33 Skostniałe wyrażenie „ostrzem miecza”, łączące się z różnymi czasownikami (zob. $H A L$ ), zdaje się tutaj nie pasować i często uważane jest za glosę powstała pod wpływem w. 16 (zob. m.in. BHS; W. Hertzberg, Die Bücher Josua, Richter, Ruth, 170 przyp. 2). Jednak wszystkie świadectwa tekstowe je poświadczają (zob. $B H Q$, gdzie wysuwa się podejrzenie, że może to być bardzo wczesne zakłócenie tekstu -

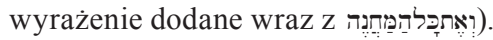




\section{i zszedł Sisera z rydwanu ${ }^{34}$, i uciekał pieszo (na swoich nogach).}

16. A Barak ścigał rydwany i całe wojsko aż do Charoszet-Haggojim, i padło całe wojsko Sisery od ostrza miecza, nie ostał się ani jeden.

17. Zaś Sisera uciekł pieszo (na swoich nogach) w stronę namiotu Jael, żony ${ }^{35}$ Chewera, Kenity, gdyż panował pokój pomiędzy Jabinem, królem Chacor

a (i pomiędzy) domem Chewera, Kenity.

18. Wtedy wyszła Jael na spotkanie Siserze i powiedziała do niego:

Zboczże, panie mój, zboczże do mnie! Nie bój się!

Gdy zboczył do niej, do namiotu, to przykryła go kocem ${ }^{36}$.

19. I powiedział do niej:

Dajże mi pić trochę wody, bo jestem spragniony ${ }^{37}$ !

Wtedy otwarła bukłak ${ }^{38}$ m mlekiem i napoiła go, i przykryła go.

20. I powiedział do niej:

Stań $^{39}$ przy wejściu do namiotu,

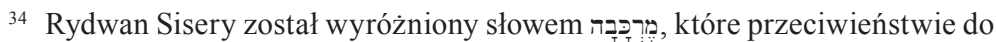
użytego w poprzednich wierszach רֶֶב jest dobrze poświadczone w wielu językach (ugaryckim, aramejskim, akadyjskim, egipskim czy koptyjskim - zob. HAL).

$35 \mathrm{~W}$ kodeksie L znajduje się błędny dageš forte (inaczej niż w kodeksie z Aleppo i kairskim kodeksie prorockim - zob. $B H Q$ ).

${ }^{36}$ Hapaxlegomen, który w Vrs przy wszystkich różnicach przetłumaczony został jako przykrycie (zob. HAL i BHQ). Nie ma więc powodu, by zakładać, że akurat w $\mathrm{G}^{\mathrm{B}}$ wyprowadzano to słowo od מִכְסָה (,przykrycie”, „osłona”; zob. BHS), choć z drugiej strony nie da się też wykluczyć, że w wielu Vrs rzeczywiście takie słowo miano na uwadze (zob. BHQ). Być może w 2 Mss mamy jego ekwiwalent (zo zamiast ש). Rzeczownik ten jest wywodzony od czasownika סמן, tj. ,chronić” (zob. HAL i $H A H A T$ ).

37 W wielu Mss mamy do czynienia z formą oboczną lub przypadkowym wypadnięciem niemego (zob. BHS).

38 Ponownie spotykane są różne formy oboczne (zob. BHS i $H A L$ ).

39 Bez względu na to, czy jest to inf. abs., co wymagałoby jednak zmiany wokalizacji, czy impt. masc. (zob. $B H Q$ ), to nie ma chyba wystraczającego powodu do zmiany na fem., tj. formę pasującą do Jael, gdyż najprostsze formy masc. nieraz stoją na początku zdania (wg Gesenius' Grammatik, § 145o, tylko gdy podmiotem 
a gdyby ktoś przyszedł i zapytał ciebie, i powiedział:

Czy jest tutaj ktoś?,

to odpowiesz: Nie ma.

21. Wtedy wzięła Jael, żona Chewera, palik od namiotu i chwyciła młotek w rękę swoją, i podeszła do niego po kryjomu ${ }^{40}$, i wbiła palik w skroń jego, tak że wszedł ${ }^{41} \mathrm{w}$ ziemię, podczas gdy on mocno spał ${ }^{42}$, a był zmęczony ${ }^{43}$, i zmarł.

22. A oto Barak ściga Siserę i wyszła Jael mu na spotkanie, i powiedziała mu:

Chodź, a pokażę ci człowieka, którego ty szukasz! Wtedy wszedł do niej, a oto Sisera leży martwy, a palik tkwi w jego skroni.

23. Tak poniżył Bóg ${ }^{44} \mathrm{w}$ tym dniu Jabina, króla Kanaanu przed Izraelitami.

24. A ręka Izraelitów ciążyła coraz mocniej ${ }^{45}$ na Jabinie, królu Kanaanu, aż wytępili Jabina, króla Kanaanu.

jest rzecz lub zwierzę, stąd w $§ 110 \mathrm{k}$ podejrzewa błąd tekstowy) niezależnie od rodzaju gramatycznego podmiotu (wypieranie form fem. przez masc.). Wbrew BHS tylko w T zmieniono rodzaj (tak BHQ). Zob. też W. Groß, Richter, 257; T.C. Butler, Judges. Przypisywanie tej formie masc. szczególnego znaczenia (zob. m.in. S. Järlemyr, „A Tale of Cross-Dressers”, 53 i poniżej) wydaje się wątpliwe.

${ }^{40}$ Pisownia pełna (w L) i defektywna w wielu Mss (zob. BHS i $B H Q$ ). Pełnej pisowni nie spotykamy w innych miejscach, gdzie występuje ten rzeczownik (,tajemnica”, „skrytość”; do tłumaczenia zob. $H A L$ ).

${ }_{41}$ Czasownik ten występuje jeszcze tylko w Joz 15,14 i Sdz 1,14, a podmiotem jest palik (zob. HAHAT; w HAL uwzględniono również możliwość, że podmiotem jest skóra skroni).

42 W niektórych Mss zamiast ptp. występuje pf. (zob. BHS). Do budowy zdania okolicznikowego stanu zob. Gesenius' Grammatik, §156c.

43 Impf. cons. następujące po ptp. (kontynuacja) nie budzi zastrzeżeń (zob. Gesenius' Grammatik, § 111u [i 116x]). Bliski związek z poprzedzającym zdaniem (okolicznikiem stanu) podkreśla też akcent łączący (zob. BHQ). Nie ma więc potrzeby korekty na przymiotnik (jak proponuje się w BHS i HAL). Zob. też Gesenius' Grammatik, § 72t; W. Groß, Richter, 257.

44 Niektóre świadectwa mają bądź dodają imię JHWH (zob. BHS; BHQ).

45 Do הלך w inf. abs. dla wyrażenia stopniowej zmiany zob. Gesenius' Grammatik, $\S 113 \mathrm{~h}$. 


\section{Budowa opowiadania}

Opowiadanie to zostało klarownie i precyzyjne skonstruowane:

w. 1-5: wprowadzenie i zawiązanie akcji

w. 1-3: nieposłuszeństwo Izraela, jego niedola i wołanie na pomoc

w. 4-5: Debora prorokinią i sędziną Izraela

w. 6-22: rozwinięcie akcji

w. 6-16: zwycięska wojna z Siserą - Debora i Barak

w. 6-9: wezwania Baraka i dialog z Barakiem

w. 6a: przywołanie i przybycie Baraka z Kedesz do Debory

w. 6b-7: Boże polecenie i obietnica pokonania Sisery

w. 8: warunek Baraka pod adresem Debory

w. 9a: akceptacja warunku, chwała dla kobiety

w. 9b: Debora z Barakiem udają się do Kedesz

w. 10: przygotowania Baraka do wojny w obecności

Debory (Tabor)

w. 11: wtrącenie - Chewer Kenita (okolice Kedesz) w. 12-13: przygotowania Sisery do wojny (Kiszon) w. 14-16: polecenie Debory, uderzenie na Siserę i rozgromienie jego wojska

w. 14a: polecenie i obietnica zwycięstwa (ostatnie słowo Debory)

w. 14b: uderzenie wojsk Baraka

w. 15a: Bóg wywołuje zamieszanie w oddziałach Sisery

w. 15b: Sisera ucieka pieszo

w. 16: Barak rozbija cała wojsko Sisery

w. 17-21: śmierć Sisery - Sisera i Jael

w. 17: uciekający pieszo Sisera

w. 18-20: zaproszenie Sisery i troska o niego - dialog Jael z Siserą

w. 21: podstępne ${ }^{46}$ zgładzenie Sisery przez Jael

46 Podstęp jest sposobem działania tych, którzy z wielu powodów są w gorszej sytuacji, tak że słowa tego nie użyto tutaj dla wartościowania czynu Jael, a jedynie 
w. 22: Barak i Jael - przybycie Baraka i odnalezienie martwego Sisery

w. 23-24+5,31b: zakończenie (rozwiązanie akcji): poniżenie i zagłada wrogów, pokój w kraju ${ }^{47}$.

Spotkania Debory z Barakiem ma podwójnie klamrową budowę. Debora posyła po niego do Kedesz (w. 6a), a po dialogu (Debora wypowiada się dwa razy, a Barak odzywa się tylko raz) udają się razem do Kedesz (w. 9b) - pierwsze obramowanie. Jedyne słowa Baraka, to żądanie, by Debora udała się razem z nim (w. 8). Po przygotowaniach do bitwy Debora drugi raz wydaje rozkaz Barakowi, w którym końcowe pytanie retoryczne (w. 14a) nawiązuje do jej pierwszego słowa (w. 6b) - drugie obramowanie. Na końcu Barak powraca jeszcze raz w okolice Kedesz, gdzie stoi namiot Jael, w którym leży martwy Sisera (w. 22). Barak jest milczącym świadkiem jej zwycięstwa. Jael prowadzi dialog z Siserą, który sama inicjuje (w. 18-20), a Sisera zwraca się do niej jedynie z bojaźliwymi prośbami. Ostatnie słowo ponownie należy do kobiety, która nakazuje Barakowi iść, by znaleźć martwego Siserę - jest to trzecia klamra kompozycyjną, łącząca obie kobiety, wydające polecenia Barakowi.

\section{Opowiadanie w kontekście literackim}

Opowiadanie o Deborze i Jael rozpoczyna się od informacji o ciężkiej sytuacji Izraela (w. 1-3). Na samym początku czytelnik dowiaduje się, że położenie Izraela wynika z jego winy. Formuła „czynić zło

dla opisania jej sprytu. Przeciwko używania wartościującej kategorii podstępu, zdrady czy uwiedzenia zasadnie występuje C. Mandolfo, „Women, Violence, and the Bible", 346.

47 Podział w W. Groß, Richter, 258-259, jest w ogólnym zarysie podobny: w. 1-3 (wprowadzenie - sytuacja Izraela), w. 4-16 (zwycięska wojna z Siserą - Debora i Barak), w. 17-21 (śmierć Sisery - Sisera i Jael), w. 22 (martwy Sisera - Jael i Barak), w. 23-24+5,31b (zakończenie - zagłada Jabina i pokój); podobnie H.-D. Neef, „Der Sieg Debora", 33: w. 1-3 (przyczyna wojny), w. 4-9 (inicjatywa Debory i udział Baraka w wyzwoleniu od Sisery), w. 10-16 (bitwa i pokonanie Sisery), w. 17-22 (zabicie Sisery przez Jael), w. 23-24 (zakończenie związane z w. 1-3 - wyzwolenie Izraela); inaczej T.C. Butler, Judges: wprowadzenie (w. 1-5), zawiązanie akcji (w. 6-8), zmiana (w. 9-11), rozwiązanie (w. 12-15), klimaks (w. 16-21), ogłoszenie (w. 22) i zakończenie (w. 23-24). 
w oczach JHWH" występuje wiele razy w Sdz, ma charakter programowy i strukturyzujący, otwierając lub zamykając poszczególne cykle narracyjne poświęcone kolejnym sędziom/sędzinom (por. 3,7; $3,12 ; 6,1 ; 10,6 ; 13,1)$. Po raz pierwszy pojawia się w programowym wprowadzeniu do cyklu opowieści czy sag o sędziach i wyzwolicielach z rozdziałów 2-16 (po śmierci Jozuego) w 2,11-3,6 $6^{48}$. To deuteronomistyczne wyrażenie (por. Pwt 4,25; 9,18; 17,2 i in.) ${ }^{49}$ w ogólny sposób krytykuje niewłaściwe w Bożej ocenie ${ }^{50}$ postępowanie Izraela, które ma wymiar nie etyczny, lecz religijny: złem jest służenie obcym bogom (Sdz 2,11-13.19) i mieszanie się z obcymi ludami (małżeństwa mieszane; por. $\mathrm{Sdz} 3,6-7)^{51}$. Pomimo wcześniejszych doświadczeń (3,7 we wprowadzeniu do historii Otniela i 3,12 na początku historii Ehuda) Izrael trwał w swym kolektywnym nieposłuszeństwie (por.

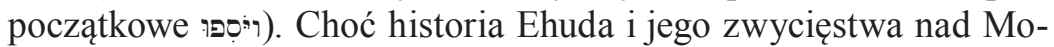
abitami kończy się w 3,30, to o jego śmierci mowa jest po krótkiej wzmiance o Szamgarze i jego zwycięstwie na Filistynami (3,31; por. tzw. Pieśń Debory Sdz 5,6). Ehud (Binjaminita/Beniaminita) poza Sdz 3 wzmiankowany jest tylko w $1 \mathrm{Krn} 7,10^{52}$. Notatka o śmierci jest typowa i poprzedza stwierdzenie o wydaniu Izraela w ręce wroga (por. 3,11b-12a; zgodnie z koncepcją z 2,19). Wydanie w rękę wroga jest kolejną typową w Sdz formułą, która występuje w dwóch wariantach: z czasownikiem מכר (w programowym 2,14 oraz w 3,8 - Otniel;

48 Do rozbudowanego wprowadzenia $\mathrm{Sdz}$ 1,1-3,6 zob. W.H. Schmidt, Wprowadzenie do Starego Testamentu, 128-129; G. Hentschel, „Das Buch der Richter”, 214-215 i bardziej szczegółowo W. Groß, Richter, 182-189.

49 Nie ma tutaj miejsca, by odnieść się do skomplikowanego zagadnienia powstania tzw. Deuteronomistycznego dzieła historycznego ani wieloetapowości redakcji deuteronomistycznych (zob. literatura wymieniona w poprzednim przypisie).

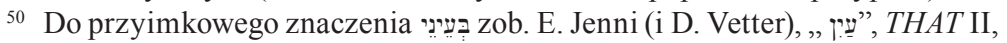
264-265.

51 Zob. D. Dziadosz, Księga Sędziów rozdziały 1-5, 406.

52 Być może formą oboczną jest אֲבְיהוּר w 1 Krn 8,3. 
10,7 - Jefte i 4,9) ${ }^{53}$ lub z czasownikiem נתן (ponownie w 2,14 oraz w 6,1 - Gedeon; 13,1 - Samson i 4,7.14) ${ }^{54}$.

Jabin (etymologia imienia nieznana) pojawia się jeszcze w Joz 11,1 - w historii, w której Jozue pokonał i zabił „króla Chacoru” (Joz 11,10-13) stojącego na czele koalicji ludów przeciwko Izraelitom ${ }^{55}$. Natomiast nie ma o nim mowy w Pieśni Debory (Sdz 5), w której „królowie Kanaanu” (w pl.) walczą pod wodzą Sisery (5,19-22). W naszym opowiadaniu z Sdz 4 naprzeciwko siebie stoją cały Izrael i król Kanaanu. Kanaan jako pojedyncza wielkość z jednym władcą na czele jest wyjątkowym wyobrażeniem w Starym Testamencie (por. też w. 17.23-24) ${ }^{56}$. Chacor (Chasor), którego królem był Jabin, leży w górnej Galilei, na terenach Naftaliego (Naftalego). Od wczesnej epoki brązu aż po czasy helleńskie było to znaczące miasto ${ }^{57}$. Stąd nie dziwi rola Chacoru zarówno w Joz 11 i Sdz 4 a nawet mające wyłącznie literacki wymiar określenie władcy Chacoru królem (całego) Kanaanu $^{58}$. Jabin siłą rzeczy był również władcą Charoszet-Haggojim, miasta Sisery. Charoszet-Haggojim, tj. Charoszet-Ludów ${ }^{59}$, może być identyczny z Tell 'Amr (El-Haritije), leżącym na północno-zachodnim

53 מכר, który zwyczajowo tłumaczony jest jako „sprzedać/kupić”, odnosi się przede wszystkim do przekazania jakiś dóbr, przeważnie ich wymiany (za coś innego wartościowego). Bóg zaś oddaje Izraelitów jego wrogom - zob. E. Lipiński, ,מבר", TWAT IV, 869-875, zwł. 870.

54 Nie ma tutaj natomiast nieregularnie pojawiającej się wzmianki o Bożym gniewie, jak w 2,14; 3,8; $10,7 \mathrm{i}$ in.

55 Jest więc sprzeczne z Sdz 4 - zob. W. Hertzberg, Die Bücher Josua, Richter, Ruth, 175; H.-D. Neef, „Der Sieg Debora”, 34. Trudno byłoby zniwelować tą sprzeczność hipotezą, że Jabin to imię nie jednostki, lecz dynastii (zob. T.J. Schneider, Judges, 59-60; D. Dziadosz, Księga Sędziów rozdziały 1 - 5, 407; a także T.C. Butler, Judges; A. Scherer, ,Jabin”). Wg W. Groß, Richter, 259-260, nazwanie króla Chacoru Jabinem bazuje na Joz 11,1-11. Jabin wzmiankowany jest też w Ps 83,10, który bez wątpienia opiera się na opowiadaniu z Sdz - zob. E. Zenger (i F.L. Hossfeld), Psalmen 51-100, 501-502.

56 Zob. H.-D. Neef, „Der Sieg Debora”, 35; T.C. Butler, Judges, według którego Kanaan jako jedna całość w rzeczywistości nigdy nie istniała.

57 Zniszczenia w XVI, XIV, XIII (przez ludy morza), IX i IX w. p.n.e. - zob.

W. Groß, Richter, 264.

58 Fikcyjnie - tak W. Groß, Richter, 265.

59 Zob. W. Hertzberg, Die Bücher Josua, Richter, Ruth, 175. 
krańcu doliny Jezreel ${ }^{60}$. Sisera, który według w. 2 jest dowódcą wojska Jabina $^{61}$, w Sdz 5 zdaje się być najważniejszym z królów ${ }^{62}$. Kananejczycy dysponować mieli 900 rydwanami, które stanowiły najpoważniejsze wyposażenie wojskowe, ukazujące ich militarną wyższość: lekkie, jednoosiowe wozy z dwoma kołami, zaprzężone w jednego lub dwa konie, z powożącym i łucznikiem. Określenie ich jako żelaznych mogłoby w najlepszym razie oznaczać, że konstrukcja pokryta była żelazem. Jednak nawet wtedy byłyby za ciężkie, tak że żelazo wskazuje przypuszczalnie jedynie na dysponowanie najskuteczniejszą w ówczesnych czasach i przerażającą bronią (być może rydwany były wyposażone w żelazne ostrza przymocowane do kół) ${ }^{63}$. Sformułowanie w w. 3 jest niejasne, tak że nie wiadomo, kto posiadał rydwany: Jabin czy Sisera ${ }^{64}$, ale w w. 13 są one jednoznacznie siłą bojową Sisery. Potęga militarna Kananejczyków umożliwiła 20-letni ucisk, ujarzmienie (לחץ) ${ }^{65}$ Izraelitów. Jest to kolejny typowy motyw w Sdz $(2,18 ; 6,9 ; 10,12$ i in.). Standardowe jest także zwrócenie się (צעק ) do Boga w niedoli ${ }^{66}$, w sytuacji militarnego zagrożenia i ucisku (por. 3,9.15; 6,6-7; 10,10, przy czym w Sdz wszędzie indziej występuje forma oboczna זעr). Nie ulega więc wątpliwości, że wprowadzenie tej opowieści zostało sformułowanie w deuteronomistycznym języku

${ }^{60}$ Tak Calwer Bibellexikon, 481, ale wg T.C. Butler, Judges, dokładna lokalizacja tego miasta nie jest znana.

${ }_{61}$ H.-D. Neef, ,Der Sieg Debora”, 35, sądzi, że podmiotem zdania w w. 2bb (וְוּ nie może być tylko Sisera.

62 Jest to niesemickie imię - zob. A. Scherer, „Sisera”; T.C. Butler, Judges i W. Groß, Richter, 265. Sisera poza Sdz 4-5 wzmiankowany jest w 1 Sm 12,9 i Ps 83,10 - tekstach zależnych od Sdz (zob. A. Scherer).

63 Zob. W. Groß, Richter, 265-266, przy czym rydwany z ostrzami na kołach pojawiają się dopiero w Persji. W szczytowym okresie swego istnienia (za Ahaba) Izrael miał posiadać 2000 rydwanów (zgodnie z monolityczną inskrypcją z Nimrud, wymieniająca siły koalicji antyasyryjskiej - zob. I. Finkelstein. N.A. Silberman, Keine Posaunen vor Jericho, 197).

64 Zob. H.-D. Neef, „Der Sieg Debora”, 35-36; W. Groß, Richter, 266, według którego sformułowanie jest świadomie niejasne.

65 Do tego czasownika, który służy często do opisu relacji pomiędzy politycznymi czy społecznymi grupami, zob. J. Reindl, ,לָָ", TWAT IV, 547-551.

${ }^{66}$ Terminus technicus na podniesienie alarmu, wzywanie na pomoc, choć użycie tego czasownika nie ogranicza się do takie znaczenia. Wołanie skierowane do Boga jest typowe dla skargi - zob. R. Albertz, ,צעק", THAT II, 568-574. 
i ma na celu jej osadzenie w redakcyjnych ramach Sdz. W obecnym kształcie jest ono jedną z powtarzających się historii o nieposłuszeństwie Izraela, jego wołaniu na pomoc do Boga, Bożej interwencji poprzez sędzinę (sędziego) i ocaleniu (po którym Izrael znów powraca do swego nieposłuszeństwa Bogu) ${ }^{67}$.

Z kontekstem Sdz jest związane także przedstawienie Debory w dru-

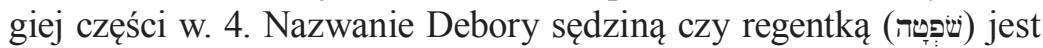
charakterystyczne dla Sdz. Redaktor deuteronomistyczny utożsamia sędziów/sędzinę z wybawicielami (ישעי; por. 2,16-18; 3,10; 10,2-3) ${ }^{68}$.

Z Sdz 2-16 opowiadanie łączą także zamykające wiersze. W. 23 mówi o poniżeniu przez Boga wrogów Izraela (כנע, por. ni. w 3,30; $8,28 ; 11,33)^{69}$. Pomimo pewnych różnić stylistycznych jest to motyw przynależący do opracowania całości $\mathrm{Sdz}^{70}$. Jak w w. 2 wrogiem Izraela jest Jabin. Imię to wraz z apozycją „,król Kanaanu” pojawia się aż trzy razy w w. 23-24, zostało więc wyraźnie uwypuklone. W końcowych wierszach znikają natomiast pozostali bohaterowie: Sisera, Barak, Debora i Jael, a nawet Zebulonici i Naftalici. Pozostają tylko Izraelici jak w w. 1-3 (w w. 4 z kolei występuje Izrael) ${ }^{71}$. Czasowa wskazówka „w tym dniu” odwołuje się do dnia z w. 14, czyli zwycięstwa Debory/Baraka i wybicia wojska Sisery, a także do w. 21 - uśmiercenia Sisery. Co ciekawe, w całym opowiadaniu

67 Wszystkie większe i mniejsze odmienności z stosunku do innych opowiadań w Sdz, co dotyczy też w. 23-24, omawia H.-D. Neef, „Der Sieg Debora”, 34-38, który wyciąga z tego wniosek (obejmujący cały rozdział), że autor ram wykorzystał trzy elementy: utrwalone sformułowania (formelhafte Gut), materiał o Siserze i o Jabinie, przy czym Jabin nie należał do pierwotnego przekazu.

68 Por. też $1 \mathrm{Sm} 4,18 ; 7,6.15-17 ; 8,1-2$ i 2 Krl 23,22. Chociaż czasownik ma przede wszystkim jurystyczno-sądowe znaczenie, to występowanie w sądzie w obronie osób społecznie poszkodowanych zbliża jego znaczenie do ratowania zob. G. Liedke, ,שפט", THAT II, 999-1004, zwł. 1002-1003. Wg T.C. Butler, Judges, taka prezentacja Debory przewraca do góry nogami świat czytelnika.

${ }^{69}$ Do tego czasownika, który spotykamy 36 razy w Biblii Hebrajskiej w późnych tekstach (też w Qumran) w pasywnym i zwrotnym ni. i aktywnym hi., zob. S. Wagner, ,כנעי,, TWAT IV, 217-219.

70 Tzw. Beugeformel - zob. W. Groß, Richter, 282-283. Można by ponadto

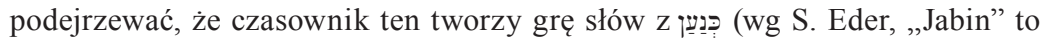
asonans; a wg E. van Wolde, ,Ya'el in Judges 4”, 241, kalambur).

71 Zob. W. Groß, Richter, 282-283. 
tylko tutaj Bóg określony został nie swoim imieniem JHWH, ale jako Elohim. W w. 2 Izraelici byli we władzy (ידָ (יר) Jabina, a dzięki Bożej interwencji on jest w końcu w władzy (ידָ ) Izraelitów. Przymiotnik קָשָה zgładzenia (do כרת por. np.1 Krl 9,7) 72 Jabina, co przypuszczalnie obejmuje jego królestwo i ludu Kanaanu. Choć w w. 24 nie odnajdujemy dalszych charakterystycznych dla Sdz sformułowań, to jest powiązany on z wprowadzającymi wierszami. W. 1-3.4b i w. 23-24 tworzą zatem obramowanie historii o Deborze/Baraku/Siserze i Jael.

Zdanie znajdujące się po Pieśni Debory (w historycznym impf. cons.) tworzy narracyjne zamknięcie cyklu o Deborze (Sdz 4-5): „Wtedy zaznał spokoju kraj przez czterdzieści lat” (5,31b). Zostało ono sformułowane w typowy w Sdz sposób: kraj odpoczywa przez 40 lat (por. 8,28 oraz 80 lat, tj. dwukrotność 40 lat, w 3,11; 5,31). 40 lat ma znaczenie symboliczne: pełny czy cały okres życia jednego pokolenia (por. Lb 14,33-34), które nie doświadczyło już kolejnych prześladowań. Czasownik שׁ (,zaznać spokoju”) z podmiotem דָָארִ (,kraj”) opisuje pokojowy okres następujący po działaniach wojennych (Joz 11,23; 14,15: po podboju ziemi obiecanej) ${ }^{73}$.

Kontekstem opowiadania jest także Pieśń Debory [i Baraka] (Sdz 5,[1.]2-31a), która uchodzi za jeden z najstarszych tekstów w Biblii Hebrajskiej ${ }^{74}$. W 5,1 Barak został dodany z pewnością wtórnie, na co wskazuje już początkowy czasownik w 3. os. sg. fem. W Pieśni, w której poeta przemawia w 1. os. sg., Debora jest bohaterką. Rozdziały 4. i 5. wiele ze sobą łączy - przede wszystkim bohaterowie Debora, Barak, Sisera, Jael, walczący Naftalici i Zebulonici, Kiszon jako miejsce bitwy (Tabor, którego nie wzmiankuje Pieśń, nie pasuje do faktycznej bitwy) ${ }^{75}$, w ogólnym zarysie sposób, w jaki Jael zabiła

72 Zob. E. Kutsch, ,כרת", THAT I, 857-860, zwł. 858.

73 Zob. W. Groß, Richter, 223.

74 Zob. W. Hertzberg, Die Bücher Josua, Richter, Ruth, 182 i szeroko W. Groß, Richter, 295-302. Do przeciwstawnych hipotez zob. ponadto A. Scherer, „Sisera”.

75 Najmniejsza odległość pomiędzy Taborem i wadi Kiszon wynosi nieco ponad 16 km (wg T.C. Butler, Judges). Zob. też W. Groß, Richter, 261-262, według którego wzmianka o Tabor jest możliwa narracyjnie, ale nie militarnie. Natomiast Megiddo i Taanach $(5,19)$ dobrze współgrają z bitwą w dolinie Kiszonu. 
Siserę. Jednak różnice są również znaczące ${ }^{76}$ : brak Jabina, koalicja królów Kanaanu, dwuznaczna postawa innych grup (stąd walczą tylko Naftali i Zebulon - 5,18), niewola Baraka, osunięcie się Sisery dopiero po roztrzaskaniu mu głowy (5,26-27). Pomijając szereg dalszych różnic (i niejasności w samej Pieśni), żadnego bezpośredniego odzwierciedlenia w opowiadaniu nie znajduje rozbudowany w Pieśni motyw matki Sisery $(5,28-30)^{77}$. Interwencja ponadludzkich sił $(5,20)$ sprawia, że wylew Kiszonu $(5,21)$ rozstrzyga bitwę (bitwy?, wezbranie potoku Kiszon i rozmiękczenie gruntu, podtopienia powodujące, że rydwany nie mogły się poruszać? $)^{78}$ na korzyść Zebulona i Naftaliego. Bez wątpienia opowiadanie i Pieśń są ze sobą powiązane, ale trudno byłoby rozstrzygnąć, czy korzystają z tej samej tradycji (ustnej?), czy też są literacko od siebie zależne, przy czym możliwe jest, że zależności takie przebiegały w obie strony w ramach wielokrotnego procesu redakcji ${ }^{79}$. Można więc i należy interpretować opowiadanie zarówno jako odrębną wielkość, jak i w odniesieniu do Pieśni Debory.

\section{4. (Pierwotne) opowiadanie w. 4-22*}

Jak już zaznaczono we wprowadzeniu, nie zajmuję się tu bliżej sprawą integralności literackiej opowiadania. Trzeba odnotować, że z ramami deuteronomistycznymi w. 1-3.4b.23-24 oraz 5,31b z pewnością związane są: perspektywa pan-izraelska w w. 5b, wzmianka o Siserze jako dowódcy wojska Jabina w w. 7a i 17, być może nawet określenie JHWH jako „Boga Izraela” w w. 6b. Istnieją i dalsze trudności: obietnica wydania Sisery w rękę Baraka w w. 14a (po w. 9b); wojsko

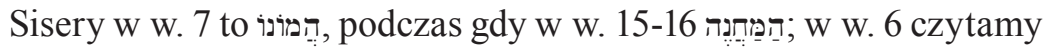

76 Nie ma tutaj miejsca ani na bliższą analizę tej trudnej Pieśni, ani na ocenę jej integralności literackiej - do tego zob. m.in. W. Groß, Richter, 337-341.

77 Ale zob. poniżej.

78 Zob. T.C. Butler, Judges. Niepewności co do interpretacji Pieśni dotyczą też 5,19-22 - zob. W. Groß, Richter, 325-332.

79 Niedawno (2011) J.L. Wright, „Deborah’s War Memorial”, 516-534, próbował dowodzić, że Pieśni Debory - poza ogólną scenerią bitwy w dolinie Jezreel, która była miejscem wielu starć - nic nie łączy z opowiadaniem z rozdz. 4, bo wszystkie związki zawdzięczamy jej wtórnemu rozszerzeniu w oparciu o opowieść z rozdz. 4. 
o „synach Naftaliego” i ,synach Zebulona”, a w w. 10 o Naftalim i Zebulonie; wzmianka o ostrzu miecza w w. $15 \mathrm{a}^{80}$. Poza tymi redakcyjnymi ingerencjami związanymi z osadzeniem opowiadania w deuteronomistycznych ramach Sdz 2-16 różnice językowe nie prowadzą do wniosku o dalszych rozszerzeniach opowiadania z w. 4-22*81. Podobnie w kwestii datowania opowiadania niech wystarczy ogólne stwierdzenie, że wiele wskazuje na to, iż pierwotne opowiadanie jest późniejsze od Pieśń Debory, a poprzedza deuteronomistyczną kompozycję Sdz ${ }^{82}$. Jeśli Pieśń Debory pochodzi z wczesnych czasów (X/IX w. p.n.e. $)^{83}$, a kompozycja deuteronomistyczna najwcześniej z okresu wygnaniowego, to opowiadanie powstało w okresie monarchicznym (przedwygnaniowym), być może nawet we wczesnym okresie monarchicznym, jako że związane jest z dwoma plemionami Naftalim i Zebulonem, a nie całym (północnym) Izraelem ${ }^{84}$.

Imię Debora oznacza dziką pszczołę (miodną - por. Sdz 14,8), która mogła być agresywna (por. Iz 7,18; Pwt 1,44; Ps 118,12) ${ }^{85}$. Narrator w pierwszym rzędzie wyraźnie zaznacza, że Debora jest kobietą. Słowo „kobieta” jest językowo zbędne (,kobieta” i ,prorokini” to

80 Do tej wzmianki zob. już powyższą uwagę do tłumaczenia.

81 Zob. W. Groß, Richter, 262-263, który z przeddeuteronomistycznego opowiadania wyklucza ponadto cały w. 5; dodatki podeuteronomistyczne (w. 11.17b), widząc w w. 11 wtrącenie w bardzo nieszczęśliwym miejscu i połączenie różnych tradycji Pięcioksięgu dotyczących teścia Mojżesza z Sdz 1,16. Różne propozycje literackokrytyczne omawia H.-D. Neef, „Der Sieg Debora”, 29-31, który następnie przedstawia własną analizę literackokrytyczną (34-49; zob. powyższy przyp. 67).

82 Do problematyki powstania i datowania opowiadania zob. W. Groß, Richter, 259 , który przedstawia i inne hipotezy powstania i datowania opowiadania; dalej też G. Hentschel, „Das Buch der Richter”, 217-281; T. Mayfield, „The Accounts of Deborah (Judges 4-5) in Recent Research”, 324-325; M. Jasinski, „Prorokini Debora - «wskrzesicielka» nadziei Izraela", 416-421.

83 Do tego szeroko W. Groß, Richter, 294-297.

${ }^{84}$ W. Groß, Richter, 82-85, uważa, że w części centralnej Sdz (2,6-12,15) mamy do czynienia z pojedynczymi opowiadaniami o bohaterach czy regentach, z których 4,17-21* o nieizraelskiej kobiecie mogłoby pochodzić nawet z końca XI w. p.n.e., a opowiadanie o Deborze - Baraku - Jael to kompozycja z VII/VI w.

${ }^{85}$ Zob. HAL i W. Groß, Richter, 269. Inaczej M. Jasinski, ,Prorokini Debora «wskrzesicielka» nadziei Izraela”, 422: „włodarka”, co w najlepszym razie mogłoby być ,etymologią ludową”. Tak na imię miała również mamka Rebeki (Rdz 35,8) - zob. jeszcze dalej. 
apozycje), ale każe czytelnikowi zwrócić uwagę na to, że Barak konfrontowany jest właśnie z kobietą ${ }^{86}$. A urząd prorocki nie odgrywa żadnej roli nigdzie więcej w Sdz (pojawia się jeszcze tylko נִישי נִביא, mężczyzna prorok w 6,8 , w późnym dodatku) ${ }^{87}$. Debora pełnia funkcję prorocką w całym opowiadaniu ${ }^{88}$. Była zamężna (por. Chulda w $2 \mathrm{Krl} 22,14)^{89}$ i była jedyną tego rodzaju prorokinią działającą w okresie przedmonarchicznym (por. jeszcze Miriam w Wj 15,20) ${ }^{90}$. $\mathrm{O}$ ile więc w. 4b łączy się z deuteronomistycznym wprowadzeniem z w. 1-3, to w. 4a może być początkiem pierwotnego opowiadania.

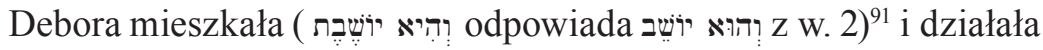
pod palmą Debory (w. 5) ${ }^{92}$. Duże drzewa odgrywały ważną rolę

${ }^{86}$ Zob. G.A. Yee, „By the Hand of a Woman”, 115; T.J. Schneider, Judges, 63-65; M. Jasinski, „Prorokini Debora - «wskrzesicielka» nadziei Izraela”, 422; S. Järlemyr, „A Tale of Cross-Dressers”, 50.

${ }^{87} \mathrm{Sdz}$ 6,7-10 to podeuteronomistyczne uzupełnienie, a to wyjątkowe w Biblii Hebrajskiej wyrażenie najpewniej opiera się na sformułowaniu z Sdz 4 - do tego zob. W. Groß, Richter, 369-370,394-395.

${ }^{88}$ Prorocki charakter działalności Debory bywa mocno podkreślany - zob. przede wszystkim E. Assis, „Man, Woman and God in Judg 4”, 118-119 (zaprzeczając jednocześnie, by miała być charyzmatyczną sędziną jak pozostali sędziowie w Sdz); T.C. Butler, Judges, który określa Sdz 4 mianem ,prorockiego opowiadania bitewnego" (prophetic battle story); M. García Bachmann, Judges, 41-74, która rozdziałowi poświęconemu Sdz 4-5 daje tytuł: Deborah: A Female Prophet Who Judged Israel („Debora: żeński prorok, który sądził Izraela”).

${ }^{89}$ Lappidot nie jest nigdy więcej wzmiankowany w Biblii Hebrajskiej, etymologia imienia jest nieznana. Bywa ono kojarzone z לַפיד (,błysk”, ,żagiew”, ,pochodnia”; zob. HAL i E. van Wolde, „Ya'el in Judges 4”, 240 i przyp. 4; T.C. Butler, Judges). Jego znaczenie nie odgrywa przypuszczalnie żadnej roli w tej historii (zob. W. Groß, Richter, 269; inaczej E. van Wolde, „Ya'el in Judges 4”, 242, według której Debora ma być tą, która „odpali” Baraka; T.J. Schneider, Judges, 66-67, dla której problematyczna końcówka pl. fem. tego imienia [przezwisko?], jak i powtórne șזָָ sprawiają, że przynajmniej możliwą interpretacją byłoby określenie Debory jako „ognistej”). Prorokiniami są tytułowane jeszcze Miriam (Wj 15,20), żona Izajasza (Iz 8,3) i Noadia w Ne 6,14.

${ }_{90}$ Miriam jest albo prorokinią w sensie ekstatycznego profetyzmu (por. $1 \mathrm{Sm}$ 10,5-6 - zob. M. Noth, Das 2. Buch Mose, 98), albo tytuł ten ma jedynie podkreślać

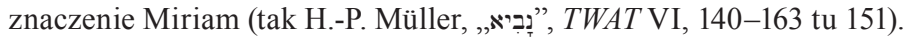

${ }_{91}$ Tj. miejscu przebywania Sisery - zob. W. Groß, Richter, 268.

${ }_{92}$ Ewentualne nawiązanie do ugaryckiej tradycji o bogini wojny Anat wzywającej bojowników i inicjującej bitwy (zob. S. Eder, „Debora / Deboralied”; T.J. Schneider, Judges, 71) nie odgrywa w opowiadaniu żadnej roli. 
kultowo-społeczną, były miejscami świętymi (Oz 4,13; Sdz 6,11.19) czy pochówku ważnych osób (1 Sm 31,13), miejscem zebrań ludu (1 Sm 14,2; 22,6), a tutaj sądu. Piastunka Rebeki imieniem Debora została pochowana pod terebintem w okolicach Betel (jeśli przekazy te są jakoś powiązane, to miejsce działalności Debory i jej palma mogą być kojarzone z „terebintem płaczu” w Rdz 35,8) ${ }^{93}$. Nazwa, której składową jest imię kobiety, jest wyjątkowa w Biblii Hebrajskiej $^{94}$. Palma Debory znajdowała się pomiędzy Betelem i Ramą, na pogórzu efraimskim. Na obszarze tym działał też Tola (Sdz 10,1-2) i Samuel (1 Sm 7,16-17). Zarówno tereny Naftalitów i Zebulonitów, jak i miejsce bitwy znajdowały w znacznej odległości (na północ) od miejsca, gdzie działała Debora. Przychodzono do niej po roz-


dla całego Izraela (tak samo jak w redakcyjnych ramach Izrael jako jedna całość) ${ }^{96}$. Cieszyła się więc uznaniem swej społeczności ${ }^{97}$ i to w zupełnie nietypowej dla kobiety roli - rozsądzającej spory. Nigdzie więcej w Starym Testamencie kobieta nie jest sędziną ${ }^{98}$.

Debora posyła - z pewnością posłańca - i wzywa Baraka (w. 6a) ${ }^{99}$. Trzy następujące po sobie zdania czasownikowe (impf. cons.) ukazują Deborę jako aktywnie działającą. Imię Baraka oznacza tyle co „błyskawica”, „błysk”"100. Jest synem Awinoama, którego imię to „ojciec (tj. Bóg) jest łaskawy"101. Mieszkał w Kedesz na terenach Naftaliego,

93 Do związku pomiędzy oboma tekstami wątpliwości nie ma W. Hertzberg, Die Bücher Josua, Richter, Ruth, 174; zob. też W. Groß, Richter, 267-268.

94 Za T.J. Schneider, Judges, 69; zob. też M. García Bachmann, Judges, 44 przyp. 6.

95 Do tego pojęcia zob. G. Liedke, ,שפט", THAT II, 999-1009, zwł. 1000-1007.

96 Zob. H.-D. Neef, „Der Sieg Debora”, 39, który wyklucza w. 5b z pierwotnego opowiadania (razem z w. 4b-5a).

97 Zob. M. García Bachmann, Judges, 42.

98 Zob. G. Liedke, ,שפט,, THAT II, 1004-1005; W.R. Osborne, „A Biblical Reconstruction of the Prophetess Deborah in Judges 4", 207. Na wyjątkowość kobiety w tej roli wskazuje T.J. Schneider, Judges, 68.

99 Oba pojęcia mogą być kojarzone z profetyzmem - zob. M. Delcor, E. Jenni, ,שלח, THAT II, 909-916, tutaj 912.914; C.J. Labuschagne, ,קרז, THAT II, 666-674, tutaj 669-670.

${ }^{100}$ Zob. HAL i W. Groß, Richter, 269.

101 Zob. HAL. 
leżącego prawdopodobne na południowym brzegu Jeziora Genezaret (16 km na północ od góry Tabor) ${ }^{102}$. Wprawdzie nazwa miejscowości związana jest ze świątynią ${ }^{103}$, jednak w opowiadaniu świątynia nie odgrywa żadnej roli. Z dalszego ciągu wydarzeń wynika, że Barak posłuchał wezwania i przybył. Sytuacja, w której kobieta wzywa mężczyznę, a ten posłusznie przybywa, mogła być dla ówczesnego odbiorcy zaskakująca ${ }^{104}$.

Mowa Debory do Baraka (w. 6b-7) zaczyna się od pytania retorycznego, emfatycznego stwierdzenia o Bożym rozkazie ${ }^{105}$. Następnie Debora przedstawia treść Bożego słowa, które składa się z polecenia (w. 6b w 2. os. sg.) oraz opisu Bożego działania wraz z obietnicą (w. 7, w którym podmiotem jest Boże ,ja”). Polecenie i obietnica ściśle sobie odpowiadają, co zaznaczono dwukrotnym użyciem czasownika משך (,pociągnąć”), które pojawia się też w Pieśni Debory $(5,14)^{106}$. Bóg JHWH, który jest Bogiem Izraela, tj. związanym z Izraelem, nakazuje (צוה pi.) (,iść”) mógłby być jedynie typowym wprowadzaniem polecenia (por. też w. 22), to jednak w opowiadaniu okazuje się kluczowym czasownikiem, gdyż Barak uzależnia wyruszenie na wojnę od pójścia z nim Debory. Biorąc pod uwagę inf. intensyfikujący, czasownik ten występuje w sumie 8 razy w w. 8-9 (z tego jeden raz w notatce narracyjnej w w. 9b). Tabor to góra czy wzgórze na północnych obrzeżach doliny Jezreel (588 m n.p.m.), na granicy pomiędzy Naftalim, Zebulonem i Issacharem (por. 5,15). Barak ma zająć pozycję na wzgórzu czy wzniesieniu, którego położenie dobrze pasuje do

102 Za W. Groß, Richter, 269.

103 Jej wariantem jest nazwa Kadesz - zob. HAL. W. Hertzberg, Die Bücher Josua, Richter, Ruth, 176-177, z miejscem świętym wiąże także Tabor jako górę, która z tego powodu miała być miejscem zgromadzenia wojska Baraka.

104 Zob. G.A. Yee, „By the Hand of a Woman”, 115.

${ }^{105}$ Zob. HAHAT; T.C. Butler, Judges; W. Groß, Richter, 269, który interpretuje to pytanie jako emfatyczną formę formuły posłańca.

${ }^{106}$ Do jego znaczenia zob. powyższą uwagę do tłumaczenia, a także H. Ringgren,

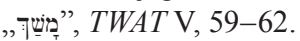

${ }^{107}$ Podmiotem jest zawsze osoba wyżej stająca na drabinie społecznej, w szczególności nakazy są wydawane w kontekście wojny i wysyłania posłańca - zob. G. Liedke, „צוה pi.”, THAT II, 530-534. 
dwóch plemion, z których miało się rekrutować wojsko Baraka. Nie zmienia to faktu, że mamy do czynienia jedynie z literackim wyobrażaniem bitwy, jako że Tabor i wadi Kiszon są zbyt odległe, by być scenerią rzeczywistej bitwy. Liczba 10 tys. jest nierealistycznie wysoka $^{108}$, ale należy do klasycznego toposu militarnego (por. 1,4; 3,39; 7,3; 20,14; 1 Sm 15,4; 2 Krl 13,7; 2 Krn 25,11-12) $)^{109}$. O ile Barak ma pociągnąć z wojskiem na Tabor, to Bóg wyprowadzi do wadi (נֵַחל) Kiszon Siserę z jego armią. Obietnica wydania Sisery w rękę (נתן בְּיד (נחד) Baraka w militarnym kontekście oznacza zawsze wydanie wrogowi (we wrogie panowanie) ${ }^{110}$.

Pomimo Bożego rozkazu i obietnicy Barak warunkuje swoją zgodę (w. 8). Wypełni polecenie, tylko jeśli prorokini Debora będzie mu towarzyszyć (הלך). Nie jest gotów tak po prostu podporządkować się Bożemu rozkazowi. Nie jest to wyraz rozsądku czy słabości, lecz nieposłuszeństwa Bożemu słowu ${ }^{111}$. Debora zapewnia o pójściu z Barakiem (emfatyczny inf.), ale obietnica JHWH wydania

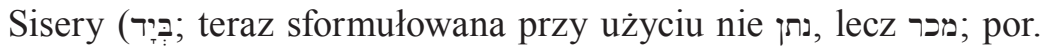
w w. 2) i związana z tym chwała przechodzi z Baraka na kobietę, w pierwszym rzędzie na Deborę (w. 9a), a jak się okaże, i na drugą kobietę ${ }^{112}$ - wyrażenie ,w rękę kobiety” jest niezdeterminowane i zajmuje emfatyczną pozycję na początku zdania (w. 9ag).

${ }^{108}$ Inaczej D. Dziadosz, Księga Sędziów rozdziały 1- 5, 419.

109 Zob. W. Groß, Richter, 269-270; też T.C. Butler, Judges.

110 Zob. A.S. van der Woude, ,דיד,", THAT I, 667-674, zwł. 671-672.

111 Zob. T.C. Butler, Judges; W. Groß, Richter, 270; D. Dziadosz, Księga Sędziów rozdziały 1 - 5, 420. Inaczej A. Bledstein, „Is Judges a Woman's Satire of Men Who Play God?", 39-40, która choć widzi w tym brak wiary, to jednocześnie w pozyskaniu tej kobiety wyraz rozsądku i gotowość do postawienia na szali swej reputacji; E. Assis, „Man, Woman and God in Judg 4”, 120.122, w ocenie którego Barak rezygnuje z własnej chwały na rzecz podporządkowania się i obecności prorockiego autorytetu. Narracja z żaden sposób nie sugeruje niedoświadczenia czy młodości Baraka (inaczej niż w przypadku powołania Mojżesza w Wj 3,11; 4,10 czy Jeremiasza w Jr 1,6), tak że doszukiwanie się tego rodzaju usprawiedliwienia nieposłuszeństwa Baraka (zob. H.-S. Bae, „Reconsidering Barak’s response in Judges 4", 504-519, na podstawie abstraktu, gdyż z powodów ograniczeń epidemicznych nie miałem dostępu do całości tekstu) trzeba ocenić jako chybione.

112 Zob. W. Hertzberg, Die Bücher Josua, Richter, Ruth, 176. 
Następujący po dialogu opis rozpoczynającej akcji (w. 9b) ponownie podkreśla rolę Debory, gdyż to ona, a nie Barak, jest podmiotem: wstaje (por. jej siedzenie w w. 5) i udaje się z Barakiem do Kedesz. Inicjatywa należała więc wyłącznie do Debory i JHWH. Dopiero po przybyciu do Kedesz, jak wynika z przebiegu narracji, Barak wzywa (w. 10; זעק w hi. dla mobilizacji wojska) ${ }^{113} 10$ tys. Nafalitów i Zebulonitów, z którymi udaje się w górę (עלה), na Tabor (por. w. 12). Wojsko Baraka to piechurzy, co kontrastuje w wyposażeniem w rydwany armii Sisery. Na końcu wiersza powtórzone zostało stwierdzenia z W. 9b, że Debora udała się (עלה) tam razem z Barakiem.

W. 11 dostarcza zaskakującą, bo pozornie niemającą związku z opowiadaniem, wtrąconą informację o zupełnie nowej osobie, o Chewerze. Wprawdzie powodem jej umieszczenia tutaj mógł być Kedesz (por. w. 10a) ${ }^{114}$, ale narrator chce również wzbudzić ciekawość odbiorcy, który siłą rzeczy liczy na to, że dowie się czegoś więcej na jego temat ${ }^{115}$. Chewer, którego imię oznacza „towarzysz” (lub ,klątwa”) ${ }^{116}$, jest Kenitą, tj. pochodzi z grupy etnicznej z Araby (por. Sdz 1,16), nomadów, którzy zostali robotnikami przy wytopie rud metalu (por. Rdz 4,22; Lb 24,21) ${ }^{117}$. Kenici w ogóle nie należeli do na stałe osiadłych grup ${ }^{118}$. Przywędrował więc $\mathrm{z}$ daleka i rozbił namiot pod terebintem - w czym przypomina patriarchów (por. Rdz 12,6; 13,18 itd.) - koło Kedesz ${ }^{119}$. Co więcej, pochodził od Chowawa, teścia Mojżesza, co do imienia którego i jego pochodzenia istnieją w Biblii Hebrajskiej różne tradycje (por. Sdz 1,16; Wj 2,16-17; 18; Lb 10,29) ${ }^{120}$. Caanannim (Q) pojawia się jeszcze w Joz 19,33, który

113 Zob. HAL.

${ }^{114}$ Wg W. Groß, Richter, 272, to jedyny sensowny powód jej wstawienia w tym miejscu.

115 Zob. T.C. Butler, Judges.

116 Zob. HAL.

${ }^{117} \mathrm{Na}$ takie zajęcie ma też wskazywać etymologia nazwy tej grupy - tak T.J. Schneider, Judges, 72, która odnajduje w tym ironię (technologia, której brakowało Izraelitom w starciu z Kananejczykami).

118 Zob. E.A. Knauf, „Keniter”,

119 Wg Z. Weisman, „Charismatic Leaders in the Era of the Judges”, 406, ,imię” to ma być w rzeczywistością określeniem subplemiennej grupy.

${ }^{120}$ Zob. W. Groß, Richter, 273. 
również wspomina terebint, a miejsce lokuje na granicy Naftaliego. Nazwa ta może pochodzić od czasownika oznaczającego ,pakować (namiot)" lub „zrywać”121, przez co mogłaby być aluzją do postępowania Chewera. Przez pokrewieństwo z Mojżeszem Chewer mógł się czuwać związany z Izraelitami i zobowiązany do solidarności ${ }^{122}$.

W w. 12 narrator powraca do głównego wątku narracji. Wiadomość o mobilizacji i zajęciu pozycji na górze Tabor dociera (נגד hi.) do Sisery. W reakcji na nią Sisera przygotowuje się i gromadzi (קיע;; por. w. 10) swoją armię, składającą się z rydwanów (por. w. 3ba) i ,całego ludu” z Charoszet-Gojjim (por. „tłum” w w. 7; w w. 16 mowa jest po prostu o wojsku Sisery). Zajęcie pozycji w wadi Kiszon (poza 5,21 Kiszon wzmiankowany jest jeszcze tylko w literacko zależnym Ps 83,10 oraz w $1 \mathrm{Krl}$ 18,40) nie może dziwić, skoro rydwany stanowiły podstawę jego sił.

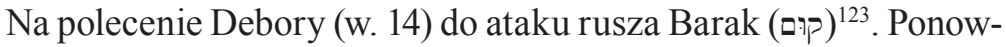
nie inicjatywa należy do Debory, która wyznacza moment uderzenia (co może - por. 2 Sm 5,24 - ale nie musi być związane z jej funkcją

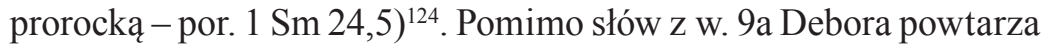
obietnicę wydania Sisery w rękę Baraka (por. w. 7b), co być może ma oznaczać pokonanie jego wojska, a nie koniecznie schwytanie samego Sisery. Wezwanie do ataku Debora kończy pytaniem retorycznym, które jest tożsame z emfatycznym stwierdzeniem (por. w. 6): JHWH idzie przed (לְפְניר) Barakiem. Jest to konwencjonalny motyw

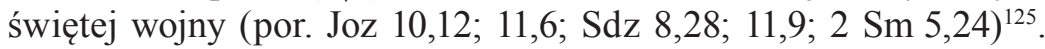
Dwa pytania retoryczne (w. 6bb i 14ad) obejmują wszystkie słowa wypowiedziane przez Deborę (klamra kompozycyjna). Debora już więcej nie pojawi się w opowiadaniu ${ }^{126}$.

${ }^{121}$ Zob. HAL.

${ }^{122}$ Tak W. Groß, Richter, 273. Związek z Mojżeszem za bardzo istotny uważa T.J. Schneider, Judges, 68-73.

${ }^{123}$ Czasownik używany m.in. określenie ataku militarnego - zob. W. Groß, Richter, 273.

124 Zob. W. Groß, Richter, 273.

${ }^{125}$ Znany nie tylko z Biblii Hebrajskiej, ale obecny też u Hetytów, w Egipcie i Mezopotamii - do tego zob. W. Groß, Richter, 274.

${ }^{126} \mathrm{Z}$ tego powodu T.C. Butler, Judges, niesłusznie pomniejsza znaczenie Debory, która miałaby być tymczasową bohaterką, a jej rola sprowadzać się do 
Barak posłusznie atakuje, schodząc z góry Tabor wraz ze swoimi dziesięcioma tysiącami, a JHWH wywołuje zamieszanie w całej armii Sisery (w. 15), w tym wśród rydwanów, przed (powtórzone z zapowiedzi z w. 14 לִקְני) Barakiem, któremu nie pozostaje nic innego, jak ścigać wojsko Sisery i je wybić (w. 16). Czasownik המם z podmiotem JHWH to terminus technicus dla paniki i przerażenia. Chętnie używany był w opisach świętej wojny w odniesieniu do wrogiego wojska (por. Wj 14,24; Joz 10,10; 1 Sm 7,10) ${ }^{127}$. Choć zamieszanie wywołał Bóg, to jednak chyba jego bezpośrednią przyczyną dla narratora miało być wojsko Baraka uzbrojone w miecze, zstępujące z Taboru (לְרִי־חֶרב, ,ostrzem miecza”, to kolejne typowe wyrażenie związane z całkowitą zagładą wrogów, a nawet wszystkiego co żywe - por. Rdz 34,26; Pwt 13,16; Joz 6,21; 10,28-11,14; Sdz 1,8; 2,15; $1 \mathrm{Sm} 22,19)^{128}$. W panice rydwany Sisery musiały się wzajemnie zablokować ${ }^{129}$, tak że Sisera ucieka pieszo. Dowódca uciekający pieszo jest tragiczno-śmieszny ${ }^{130}$. Zejście ( ירד) z rydwanu odpowiada zejściu wojska Baraka z Taboru. Jest to jeden ciąg zdarzeń, na końcu którego znajduje się ręka Jael (w. 18) ${ }^{131}$.

Wojsko Sisery ucieka w stronę Charoszet (w. 16), a Barak ściga rydwany, które nie były w stanie szybko zbiec, i całe wojsko, wybi-

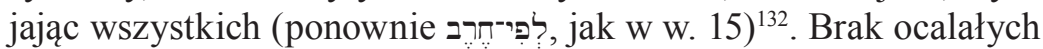
podkreśla totalność zagłady. Całkowite zwycięstwo, z którego nikt z wrogów nie uchodzi z życiem, jest również typowym motywem dla tradycji o wojnach JHWH (por. Wj 14,28; 1 Sm 11,11 i Joz 8,22.26.27

przygotowania udziału Jael i do odrzucenia Baraka. Odwrotnie E. Assis, „The Hand of a Woman: Deborah and Yael (Judges 4)”, 10-11, który równie niesłusznie uważa, że Jael odgrywa wtórną rolę względem Debory, jest właściwie przedłużeniem ręki Debory.

127 Zob. H.-P. Müller, „המם", TWAT II, 449-454, zwł. 450-451; T.C. Butler, Judges.

${ }^{128}$ Zob. W. Groß, Richter, 274, który z tego powodu uważa, że nic nie uzasadniałoby usunięcia tych słów.

${ }^{129}$ Do tego zob. powyżej.

${ }^{130}$ Zob. G.A. Yee, „By the Hand of a Woman”, 116; T.J. Schneider, Judges, 76.

131 Zob. W. Groß, Richter, 274.

132 Po JHWH z w. 15 następuje zmiana podmiotu, w w. 16a jest nim Barak, a w w. 16b wojsko Sisery. Wg W. Groß, Richter, 274, narrator sygnalizuje w ten sposób, że Barak nigdzie nie jest podmiotem chwalebnych działań. 
i in. $)^{133}$. Cały kompleks motywów: wezwanie do walki przez JHWH lub proroka, formuła wydania wroga, bezpośrednia pomoc JHWH w postaci sprowadzenia wrogiej armii na pole walki, wysłania do walki, zamieszania we wrogim obozie, oraz całkowite zwycięstwo, jest charakterystyczny dla wojen $\mathrm{JHWH}^{134}$. Jednak opowiadanie nie ogranicza się do tej tradycji, co najwyraźniej widać po działaniu Jael.

W w. 17 narrator zwraca się z powrotem ku Siserze, podejmuje opowiadanie od momentu, w którym go zostawił uciekającego pieszo (נוּם בּרבגְּליוי) W w. 15b. Sisera zmierza do namiotu Jael, która nagle pojawia się w opowiadaniu, co zdaje się odpowiadać nagłemu zniknięciu Debory w w. 14a. Jael jest żoną Chewera Kenity, o którym czytaliśmy w w. 11. Jej imię poza Sdz 4-5 nie pojawia się więcej w Starym Testamencie, a oznacza kozicę górską ${ }^{135}$. Kierunek ucieczki nie był przypadkowy, bo panował pokój (שָׁלום), tj. harmonijne współżycie (por. $1 \mathrm{Sm} 7,14 ; 1 \mathrm{Krl}$ 5,26), pomiędzy Jabinem i Chewerem (w. 17b) ${ }^{136}$. Chewer obozował koło Kedesz, skąd Barak wyruszył na Tabor. Sisera próbował zatem zmylić pościg ${ }^{137}$, jako że Barak prowadził pościg kierunku Charoszet, a Sisera uciekał w przeciwną stronę, co nawet zostało zasygnalizowane gramatycznie za pomoca przeciwstawienia podmiotów (Barak/Sisera) umieszczonych w emfatycznych pozycjach na początku (złożonych zdań rzeczownikowych) w. 16 i 17. Chewer podobnie jak mąż Debory nie pełni żadnej roli, jest niejako elementem scenerii ${ }^{138}$.

${ }^{133}$ Charakterystyczne jest w szczególności wyrażenie ,aż nie pozostał żaden ocalony/zbiegły" - zob. W. Groß, Richter, 278.

${ }^{134}$ Do tego zob. W. Groß, Richter, 275-279.

${ }^{135}$ Ewentualnie koziorożec - zob. S.C. Layton, „Ya'el in Judges 4: An Onomastic יעל Rejoinder", 93-94; HAL. Z kolei wg E. van Wolde, „Ya'el in Judges 4”, 244, imię ma być nie tylko formą impf. masc. עלה, przez co ma wskazywać na męską i symboliczną naturę jej czynu, ale i być aluzją do wejścia Debory (עלה) z Barakiem na Tabor i wyjścia Jael (צי) do Sisery i Baraka (w. 18.22). Nie jest to w żaden sposób przekonującą interpretacja - do tego zob. też S.C. Layton.

${ }^{136}$ Narrator najwyraźniej nie przejmował się nieproporcjonalnością wiodącego półnomadyczne życie Chewera i Jabina, króla Chacoru (por. Rdz 34).

137 Zob. T.C. Butler, Judges.

138 Zob. W. Groß, Richter, 280. 
Jael wychodzi naprzeciwko Sisery (w. 18, nie dowiadujemy się, czym jest ona powodowana) ${ }^{139}$, przejmując inicjatywę ${ }^{140}$, w czym jest podobna do Debory. Nakłania go (powtórzony impt.) do wstąpienia do niej, skorzystania z gościny ( סוּ - por. Rdz 19,2-3; 2 Krl 4,8.10-11; Prz 9,4.16) ${ }^{141}$ i oferuje mu ocalenie (formuła „nie bój się”; por. Rdz $43,23)^{142}$. Jael zwraca się do Sisery, nazywając go ,panem”, czyli sytuuje siebie samą jako podporządkowaną (zwrot grzecznościowy) ${ }^{143}$. Ale jej uprzejma gościnność okaże się pułapką ${ }^{144}$. Sisera usłuchał Jael, kieruje się do namiotu (ס: (ס) ${ }^{145}$, a Jael go przykrywa, dając mu dodatkowe zabezpieczenie ${ }^{146}$. Przykrycie to zdaje się ośmieszać dowódcę wojska ${ }^{147}$. Można przypuszczać, że Jael całkiem go zakryła, by w ogóle nie było można się zorientować, że ktoś jest w namiocie

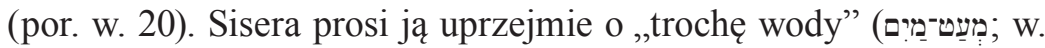
19), a Jael poi go mlekiem z bukłaka (czy należy to kojarzyć z jej

139 Zob. m.in. T.C. Butler, Judges, gdzie przedstawiono krytycznie kilka hipotez. Wg T.J. Schneider, Judges, 76-77, Chewer był związany z Izraelitami pokrewieństwem, a z Jabinem umową; a zdaniem W. Groß, Richter, 279, Jael tkwi w konflikcie pomiędzy solidarnością z Izraelitami i pokojem z Jabinem. Jednak narrator w typowy dla opowieści starotestamentowych sposób nie informuje nas o uczuciach i motywacjach bohaterów, co podkreśla również C. Mandolfo, „Women, Violence, and the Bible", 348-349.

${ }^{140}$ Wg E. van Wolde, ,Ya'el in Judges 4”, 244, odróżnia ją to od Baraka.

${ }^{141}$ Zob. W. Groß, Richter, 280. W tym zaproszeniu chętnie odnajdowano aluzję do seksualnej propozycji, do romansu (zob. T.C. Butler, Judges; G.A. Yee, „By the Hand of a Woman", 116,125, która czyni z tego nawet zasadniczą oś swojej interpretacji postaci Jael; E. Assis, „The Hand of a Woman: Deborah and Yael [Judges 4]”, 9-10; T.J. Schneider, Judges, 79; dużo ostrożniej M. García Bachmann, Judges, 52). Jednak narrator ukazuje jedynie matczyną troskę Jael o Siserę (aspekt redukcji mężczyzny do dziecka dostrzega też T.C. Butler; zob. też D. Dziadosz, Księga Sędziów rozdziały 1 - 5, 431).

${ }^{142}$ Zarówno w świeckim, jak i teologicznym kontekście pojawia się zawsze w sytuacji potrzeby, nieszczęścia oraz wiąże się z udzieleniem pocieszenia czy pomocy - zob. H.-P. Stähli, ,יראי,", THAT I, 765-778, tu 772.

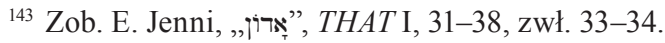

${ }^{144}$ Wg W. Hertzberg, Die Bücher Josua, Richter, Ruth, 177, Jael miała w odrażający sposób złamać ,święte na starożytnym Bliskim Wschodzie prawo gościnności”.

${ }^{145}$ Być może Jael miała własny namiot (por. Rdz 18,6; 31,33) - zob. m.in.

T.J. Schneider, Judges, 78.

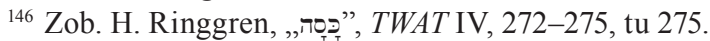

147 Tak ocenia W. Groß, Richter, 280. 
imieniem? $)^{148}$, traktując go nie tylko gościnnie, ale i po matczynemu. Po czym ponownie go przykrywa - powtórzenie to podkreśla strach Sisery. Jest on zmęczony i przestraszony, a Jael troskliwa i opiekuńcza. Sisera zwraca się drugi raz do Jael (w. 20), by go pilnowała ${ }^{149}$, stojąc u wejścia namiotu i ewentualnie informując przychodzących, że nie ma u niej nikogo. Chce się jeszcze bardziej zabezpieczyć, co dodatkowo uwypukla przerażenie Sisery.

Jael - przypomniano, że jest żoną Chewera - postępuje jednak całkiem inaczej niż można by oczekiwać po tym, co wcześniej uczyniła. W. 21 opisuje szczegółowo jej czyn za pomocą pięciu zdań czasownikowych. Czytelnik przygląda się każdemu jej ruchowi: wzięcie palika, chwycenie młotka, podejście po kryjomu (por. $1 \mathrm{Sm}$ 24,5; Rt 3,7), przebicie skroni Sisery i wbicie się palika ${ }^{150} \mathrm{~W}$ ziemię. Relacja jest sucha i precyzyjna ${ }^{151}$. Jej ręka, która chwyciła za młotek, jest ostatecznie ręką z zapowiedzi Debory w w. 9a ${ }^{152}$. Na końcu, czyli z pewną zwłoką, narrator informuje o okolicznościach, które umożliwiły zabicie Sisery: zmęczony zasnął (wyraźnie oznaczono zmianę

148 Tak ponownie W. Groß, Richter, 280. Jest to bukłak, a nie pierś Jael, jak chciałaby T.J. Schneider, Judges, 79.

${ }^{149}$ W ocenie S. Järlemyr, „A Tale of Cross-Dressers”, 53, Sisera kwestionuje tym samym swoją męskość.

${ }^{150} \mathrm{Wg}$ W. Groß, Richter, 281, palik musiał być metalowy. Tak czy inaczej stoi on w opozycji do miecza wojowników (por. w. 15-16), jest przedmiotem codziennego użytku. Całkiem możliwe, że w nomadycznych grupach na starożytnym Bliskim Wschodzie rozbijanie namiotów było zadaniem kobiet - zob. C. Mandolfo, „Women, Violence, and the Bible", 349.

${ }^{151}$ Opis postępowania Jael, który ma szereg wspólnych elementów z 5,24-27, jest szczegółowy i spójny, czego nie można powiedzieć o jego poetyckiej wersji z Pieśni Debory - zob. W. Groß, Richter, 281.

${ }^{152}$ Zob. E. van Wolde, „Ya'el in Judges 4”, 244. M. García Bachmann, Judges, 50-51, odnajduje w słowie „ręka” aluzję do penisa, tak że Jael nie może zostać jednoznacznie przypisana żadnej kategorii genderowej, należałaby raczej do „queer”, z czym miałby być też związany impt. masc. w w. 20. Reprezentować ma ona wiele tożsamości genderowych. Interpretacja taka byłaby jednak trudna do obrony. Znaczenie דיך jako fallusa jest niepewne (zob. HAHAT), nic nie sugeruje, by ręka Jael, którą bierze młotek, miałaby nie być rozumiana dosłownie (zaś w w. 9a może być też interpretowana jako władza, siła - do znaczenia tego rzeczownika zob. HAHAT), a do impt. w w. 20 zob. powyższą uwagę do tłumaczenia. 


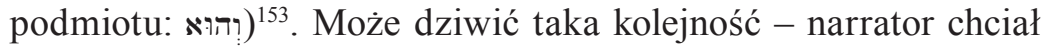
z pewnością wywołać efekt zaskoczenia działaniem Jael (w. 21a) ${ }^{154}$. Sisera, ponosząc śmierć z ręki kobiety, i to przerażony, ukryty przez nią w namiocie, zostaje okryty hańbą (por. Sdz 9,53-54) ${ }^{155}$.

Barak (w. 22) zjawia się po wszystkim. Narrator umieszcza czytelnika dokładnie w momencie tych zdarzeń - zamiast historycznego impf. cons. posługuje się הִגִ (zaimkiem deiktycznym) i zdaniem rzeczownikowym (ptp.). Barak wciąż ściga wroga (רדףjak w w. 16). Jael wychodzi mu naprzeciw, tak samo jak Siserze (por. w. 18), zachęcając do przyjścia, jednak bez zwrotu grzecznościowego, tj. w opozycji do w. 18. Jael rozmawia z pozycji wyżej stojącej na drabinie społecznej

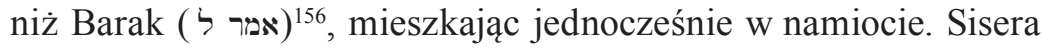
i Barak są w pewien sposób podobni, a przede wszystkim zależni od aktywności kobiety/kobiet ${ }^{157}$. Barak po raz drugi słyszy z ust kobiety polecenie ,idź!” (por. impt. הלך w w. 6, który otwierał Boże polecenie) ${ }^{158}$ (,,iść”) odegrał centralną rolę w w. 6-9, pokazując uzależnienie Baraka od działania Debory. Ponownie jest podległy kobiecie. Jael chce pokazać (1. os.) Barakowi człowieka, którego on - gramatycznie zbędny, uwypuklony podmiot „ty” - szuka. Sisera zdołał zmylić wojownika ${ }^{159}$, ale nie Jael. Jael też nie ma wątpliwości, kogo szuka Barak (דָאיש:). Od początku do końca działała zatem całkowicie świadomie. Barak wchodzi do namiotu i widzi - ponowne wskazanie na równoczesność z momentem narracji (הְִּ i zdanie

153 רדם odnosi się zawsze do twardego snu, w którym człowiek nie jest świadomy tego, co się dzieje i który uniemożliwia jakąkolwiek reakcję - por. Jon 1,5-6 czy

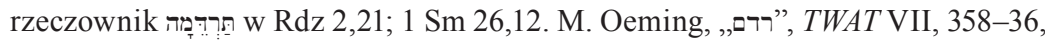
zwł. 360, użycie czasownika w Ps 76,[6.]7 interpretuje jako komę.

154 Zob. T.C. Butler, Judges.

155 Zob. A. Brenner, „A Triangle and a Rhombus in Narrative Structure”, 132.

${ }^{156}$ W. Groß, Richter, 282, za (E. Jenni) wskazuje, że mowa wprowadzona אמר z przyimkiem skierowana jest do osoby wyżej postawionej lub równej mówiącemu, podczas gdy $\mathrm{z} \succ$ do kogoś podporządkowanego, młodszego czy znajomego.

${ }^{157} \mathrm{Wg}$ W. Groß, Richter, 281-282, opowiadanie chce wyraźnie zestawić te dwa spotkania, zacierając otoczenie, bo przecież Barak zjawić się musiał nie sam, lecz z żołnierzami.

158 Zob. E. van Wolde, ,Ya'el in Judges 4”, 243.

159 Na co wskazuje בקש - do tego czasownika zob. G. Gerleman, ,בקשיע, THAT I, 333-336, zwł. 333. 
rzeczownikowe z ptp.) - martwego Siserę z palikiem w skroni. Sisera w namiocie Jael znalazł śmierć, a Barak wstyd ${ }^{160}$. Obaj mężczyźni zostali zawstydzeni w przeciwieństwie do i przez mądre bohaterki Deborę i Jael. Wprawdzie Jael raczej nie mogła wiedzieć, że jest Bożym narzędziem, ale działała, dobrze wiedząc, co robi. Mimo to inaczej niż w innych opowiadaniach w Sdz brak tu pojęcia (,wybawiciel”, por. 3,9.15; 6,36) ${ }^{161}$ czy czasownika ישע hi. (,ratować”, „ocalać”, który dziewiętnaście razy wystękuje w Sdz 2-13, np. w 2,16.18).

Narrator w żaden sposób nie sygnalizuje, że czyn Jael, który może być szokujący z powodu swej brutalności ${ }^{162}$, miałby być problematyczny ${ }^{163}$. Wręcz przeciwnie, zgodnie z zapowiedzią Debory z w. 9a wiąże się z uznaniem, chwałą. Być może - jak inni sędziowie i ludzcy bohaterowie/bohaterki w Sdz - Jael jest jednocześnie postacią nieco dwuznaczną, nieidealną ${ }^{164}$. Trzeba pamiętać, że walki plemion izraelskich/Izraela w Sdz miały przede wszystkim charakter obronny i miały zapewnić przetrwanie słabszych grup ${ }^{165}$. Co więcej, w komentarzach trudno odnaleźć jakąkolwiek wzmiankę o tym, by wybicie wrogiej armii było negatywnie oceniane, w przeciwieństwie do aktu kobiety zabijającej wodza tego wojska. Zainteresowanie sceną mordu na Siserze wynika nie tylko z jej dramaturgii ${ }^{166}$, ale również jej aspektu genderowego - skandalu, że kobieta uśmierca wojownika ${ }^{167}$.

${ }^{160}$ Tak W. Groß, Richter, 282. Inaczej A. Brenner, „A Triangle and a Rhombus in Narrative Structure", 131, która twierdzi, że nacisk położony jest raczej na spełnienie Bożej obietnicy niż wstyd Baraka.

161 Zob. W. Groß, Richter, 282.

162 Zob. T.C. Butler, Judges.

163 Co zauważono również w H.W. Hertzberg, Die Bücher Josua, Richter, Ruth, 182; D. Dziadosz, Księga Sędziów rozdziały 1-5, 437. Wg S. Järlemyr, „A Tale of Cross-Dressers", 55, Jael to archetypiczna femme fatale.

164 Tak ocenia T.C. Butler, Judges, ale zob. S. Järlemyr, „A Tale of Cross-Dressers”, 52.

165 Zob. G.A. Yee, „By the Hand of a Woman”, 111.

${ }^{166}$ Motywacji Jael i ocenie jej czynów z różnych punktów widzenie poświęcony jest D. Elgavish, „Ya'el, Wife of Heber the Kenite, in Biblical Perspective”, 78-100, gdzie końcowym wnioskiem jest, że dylematy te biblijny narrator pozostawił czytelnikowi. Taki sam wniosek formułuje M. Navarro Puerto, Księga Jozuego, Sędziów i Rut, 105-106.

${ }^{167} \mathrm{Na}$ niepokojący aspekt metafory kobiety-wojownika wskazuje przede wszystkim G.A. Yee, „By the Hand of a Woman”, 105-108; podobnie też M. García 
Opowiadanie ma czterech bohaterów, dwóch mężczyzn i dwie kobiety, którzy zawsze występują parami (Debora i Barak / Barak i Sisera / Sisera i Jael / Jael i Barak) ${ }^{168}$, przy czym nie tylko Debora i Jael, ale również Barak i Sisera nigdy za życia się nie spotykają. Opowiadanie ma jeszcze jednego bohatera. Do bitwy dochodzi z Bożej inspiracji (w. 6-7) ${ }^{169}$. Bóg sprawia, że wojska Sisery wpadają w zamęt, a rydwany nie mogą się poruszać (w. 15a), tak że Barakowi pozostaje jedynie ścigać i dobijać wojsko Sisery (w. 16). Gdyby nie interwencja Jael, być może udałoby mu się ujść z życiem. Z obietnicy w w. 9a wynika, że Jael staje na drodze Sisery z Bożej inspiracji. Z ludzkiego punktu widzenia Naftalici i Zebulonici dysponujący jedynie piechotą w starciu z dziewięciuset rydwanami nie mieli żadnym szans na sukces. Boże działanie odmieniło jednak układ sił. A przysłowiową kropkę nad ,i, postawiła Jael, przez co odniesiono pełne zwycięstwo.

\section{Kobiety i mężczyźni - role genderowe}

Panowanie, wojna, rozstrzyganie sporów były i często są typowymi męskimi domenami. Kobiety były natomiast najczęściej córkami/ żonami, matkami, opiekowały się dziećmi i domem, co obejmowało również uprawę roli, hodowlę zwierząt czy wykonywanie drobnych prac rzemieślniczych ${ }^{170}$. Bohaterowie opowiadania występują $\mathrm{w}$ takich tradycyjnych rolach. Na czele wojsk stoją mężczyźni - Sisera i Barak. Barak mobilizuje ,pospolite ruszenie” Naftalitow i Zebulonitów, a w drodze na górę ,jedynie” towarzyszy mi Debora (w. 10). Podobnie swoją armią z rydwanami zwołuje Sisera (w. 13).

Bachmann, Judges, 56-60. Inaczej C. Mandolfo, „Women, Violence, and the Bible”, 342-352, która - odrzucając wszelkie spekulacje dotyczące motywacji i położenia Jael (i Debory) oraz ich roli w patriarchalnym świecie - dowartościowuje przemoc kobiet, przez którą wcale nie wchodzą w męskie role, ale zyskują podmiotowość i możliwość kierowania swoim życiem.

168 Zob. W. Groß, Richter, 283.

${ }^{169}$ Wg E. van Wolde, ,Ya'el in Judges 4”, 246, w opowiadaniu mamy trzech faktycznych bohaterów: Boga i dwie kobiety.

${ }^{170}$ Zob. J. Slawik, „O rolach kobiet w Starym Testamencie (Biblii Hebrajskiej)”, 9-30, zwł. 10-11. Kobiety pojawiają się w Biblii Hebrajskiej i w innym rolach. 
Mężczyźni-dowódcy ruszają do bitwy ze swymi oddziałami (w. 14b-15a). Obie bohaterki - Debora i Jael są określane jako żony (w. 4a i 17.21aa) ${ }^{171}$, przy czym ich mężowie nie pełną w narracji żadnej roli, a są jedynie wzmiankowani (uprzywilejowana męskość nie wymagała odnotowania). Fakt bycia żoną zostaje szczególnie mocno uwypuklony w przypadku Jael: narrator wpierw w dość zaskakujący sposób wprowadza do opowieści tylko jej męża Chewera (w. 11), a później dwa razy powtarza informację, że jest żoną Chewera (w. 17 i w. 21, bezpośrednio poprzedzając tą informacją zabicie Sisery). Jednocześnie nawet nie wiemy, gdzie się podziewa Chewer, gdy Jael przyjmuje gości(a) w namiocie ${ }^{172}$. Jael opiekuje się Siserą jak matka, zapewnia mu ocalenie i kryjówkę (w. 18.19b), poi mlekiem (w. 19a) ${ }^{173}$. Ma też czuwać przy wejściu do namiotu, by nikt nie próbował sprawdzić, czy go tam nie ma.

Głównymi bohaterkami są bez wątpienia kobiety. Debora jest sędziną, regentką w przedkrólewskim Izraelu, uznawaną przez otoczenie $^{174}$, co w szczególności podkreśla fakt, że rozstrzygała spory sądowe (w. 5b), choć była to domena mężczyzn: króla (por. Ps 72; Prz 29,14; 2 Sm 15,2-6; 1 Krl 3,13-28) lub królewskich przedstawicieli (por. Iz 1,23) czy starszych w bramie (por. Rt 4,2; Hi 29,7-17), a w późniejszych czasach również kapłanów (por. 2 Krn 19,8) ${ }^{175}$. Była pierwszą prorokinią w historii Izraela, którą Bóg posłużył się do zwycięstwa dwóch plemion nad Siserą (w ramowych wierszach reprezentującego Jabina i Kanaan) ${ }^{176}$. Barak przybywa na jej wezwanie

171 T.J. Schneider, Judges, 66-67 i 77, wątpi, że interpretacja jako ,żona” jest to prawidłowa, bo ma raczej chodzić o przynależność tych kobiet do klanów rodzinnych Lappidota (ale zob. już powyżej) i Chewera.

172 Zob. T.C. Butler, Judges.

173 Zob. A. Bledstein, „Is Judges a Woman's Satire of Men Who Play God?”, 40.

174 Zob. E. Assis, „Man, Woman and God in Judg 4”, 118-119. Natomiast T.C. Butler, Judges, twierdzi, że narrator ma krytykować społeczeństwo izraelskie za oparcie się na kobietach w sytuacji zagrożenia i w pełnieniu ważnych funkcji publicznych. Jednak opowiadanie w żaden sposób nie krytykuje bohaterek, tak że interpretacja tak zdradza uprzedzenia komentatora wobec znaczącej roli kobiet.

175 Do szczegółów i rekonstrukcji historycznej zob. F. Crüsemann, Die Tora.

${ }^{176}$ Ze względu na dużą niepewność co do tego, czy opowiadanie odzwierciedla rzeczywiste stosunki społeczne w przedmonarchicznym Izraelu, problematyczne jest twierdzenie w G.A. Yee, „By the Hand of a Woman”, 111-112, że przywództwo 
(bynajmniej nie przychodzi zapytać się o Bożą wolę - por. Sdz 1,1; 18,5; 20,23; Joz 9,14 itp.). Debora przekazuje mu Boże polecenie i obietnicę pokonania wroga (w. 6). Jednak reakcja Baraka jest zaskakująca, bo uzależnia wypełnienie Bożego nakazu od Debory, od tego, czy wyruszy razem z nim (w. 7). Warunek ten jest zresztą jedyną wypowiedzią Baraka w całym opowiadaniu. To Debora jest prawdziwym „mężem” Bożym, a Barak zależnym, bojaźliwym czy może niezdecydowanym przywódcą. Debora musi mu cały czas towarzyszyć, co podkreśla powtarzające się zdanie ,i poszła z nim/ Barakiem" (w. 9b.10b). Nie wódz armii Barak, ale Debora decyduje również o samym momencie wyruszenia do bitwy (w. 14a). Polecenia kierowane do Baraka wzmocniono zapewnieniami w postaci pytań retorycznych (w. 6b i 14a), które zdają się sugerować niezdecydowanie Baraka. Debora jest faktyczną dowódczynią, nawet jeśli to Barak musi wyruszyć do bitwy (w. 14b) ${ }^{177}$. W związku z postawą Baraka obietnica ostatecznego zwycięstwa przechodzi na kobietę wraz z wynikającym z tego uznaniem (w. 9a). Jak się okazuje, obietnica ta dotyczy nie tylko Debory, ale przede wszystkim Jael. Debora zapowiada i wyznacza koniec wojska Sisery, ale samego Siserę zabija Jael.

Obie bohaterki łączy pokonanie Sisery, czego dokonują wspólnymi siłami, mimo że nigdy się nie spotykają. Siserze udaje się poprzez ucieczkę w odwrotnym kierunku zmylić Baraka, ale na drodze staje mu Jael. Narrator milczy na temat jej motywów ${ }^{178}$. Nie dowiadujemy się niczego o tym, dlaczego zaprasza, a potem zabija Siserę. Możemy się jedynie domyślać, że Sisera z powodu pokoju panującego pomiędzy Jabinem i Chewerem (w. 17b) mógł uważać oferowane schronienie za bezpieczne. Jednak wzmianka o Jabinie dowodzi, że jest to informacja związana dopiero $z$ deuteronomistycznymi ramami opowiadania. W pierwotnym opowiadaniu przyjęcie zaproszenia przez Siserę mogło tłumaczyć tylko jego skrajne zmęczenie. Narrator przemilcza również nieobecność Chewera, jak i dwuznaczność

wojskowe Debory było możliwe ze względu na zasadniczo domową organizację społeczeństwa (brak granicy pomiędzy tym co domowe, a tym co publiczne).

177 Zob. przede wszystkim G.A. Yee, „By the Hand of a Woman”, 110; też W. Groß, Richter, 284, według którego Debora działa poprzez słowo i swoją obecność.

${ }^{178} \mathrm{Wg}$ W. Groß, Richter, 285, Jael to najbardziej zagadkowa postać. 
zaproszenia przez kobietę do namiotu ${ }^{179}$. Wydawać by się mogło, że obietnica Jael jest szczera, że opiekuje się nim jak matka. Jednak w w. 21 akcja przybiera nieprzewidziany obrót, jest całkowitym zaskoczeniem dla czytelnika. Jael palikiem do namiotu, sprzętem z gospodarstwa domowego, brutalnie uśmierca Siserę. Wychodzi na spotkanie także Barakowi i zaprasza go, ale w rzeczywistości wydaje mu właściwie polecenie (impt., bez zwrotu grzecznościowego - w. 22). Barak przekonuje się, że zgodnie z zapowiedzią Debory (w. 9a) Sisera wpadł w rękę kobiety. Ginie nie od miecza, lecz od palika do namiotu w ręce kobiety. Barak jest tylko świadkiem odważnych działań obu kobiet ${ }^{180}$. Kobiety okazują się prawdziwymi wojowniczkami, dzięki nim Izrael, a w pierwotnym opowiadaniu Naftalici i Zebulonici odnoszą spektakularne zwycięstwo.

Matczyna troska, palik do namiotu tylko pozornie osadzają Jael w rolach genderowych przypisywanych kobietom, poza które odważnie występuje, zabijając dowódcę wojska i wydając polecenie Barakowi. Można odnieść wrażenie, że Jael pojawia się w tradycyjnych rolach, by z całą mocą skonfrontować czytelnika z jej faktycznym działaniem: odważnym, przywódczym i zgodnym z Bożą obietnicą ${ }^{181}$. Także Debora, poza wzmianką o byciu żoną, pełni role genderowe przypisywane mężczyznom: rozstrzyganie sporów sądowych, wezwanie dowódcy, rozstrzygnięcie o momencie ataku. Jedynie rola prorocka nie była przypisana tylko mężczyznom, czego najlepszym przykładem jest Chulda.

179 Tylko w świetle ostrzeżeń przed obcą kobietą z Prz 2; 5; 7 (6,20-35 to z pewnością ostrzeżenie przed współżyciem z żoną drugiego mężczyzny - do tego zob. O. Plöger, Sprüche Salomos, 67-72 i M. Sæbø, Sprüche, 100-109; do problematyki obcej kobiety w Prz zob. m.in. R. Martin-Achard, , רזт”, THAT I, 520-522; L.A. Snijders, ,זרוּוּר wątpliwości, czy zaproszenie Sisery nie miało jakiegoś podtekstu seksualnego, ale uciekający, przerażony i wycieńczony mężczyzna z trudem mógłby być adresatem takiego zaproszenia (zob. M. García Bachmann, Judges, 52).

${ }^{180} \mathrm{Wg}$ W. Groß, Richter, 284-285, Barak to najsmutniejsza postać opowiadania, któremu nic się nie udaje i może jedynie przyglądać się dokonaniom Boga i kobiet.

${ }^{181}$ Stąd racji nie ma S. Järlemyr, „A Tale of Cross-Dressers”, 61-62, według której opowiadanie ukazuje zwariowany świat pomieszania ról genderowych, w którym kobiety wcale nie są pozytywnymi bohaterkami, a krytykuje się braki męskości męskich bohaterów. 
Mężczyźni są postaciami drugoplanowymi, we wszystkim kierowanymi i zależnymi od kobiet. Obaj są negatywnymi bohaterami, słabymi, zagubionymi ${ }^{182}$, wręcz żałośnymi ${ }^{183}$. Sisera ma wprawdzie mnóstwo wojska i rydwanów, ale gdy dochodzi do bitwy ucieka na piechotę. Zdążając w stronę Jael, zmierza ku swojej śmierci. Jest zmęczony, spragniony i bardzo przestraszony. Jedyne słowa, które wypowiada, to prośby o napojenie i opiekę ${ }^{184}$. Zachowuje się jak dziecko - nakarmione, otulone i strzeżone przez kobietę ${ }^{185}$. Zasypia, a wtedy spotyka go śmierć - hańbiąca dla wielkiego wojownika z ręki, wydawałoby się, bezbronnej i opiekuńczej kobiety. Sisera pozbawiony wojennych ,zabawek” (wojska i rydwanów) okazuje się słabym dzieckiem. Barakiem, który nie zważa nawet na Bożą obietnicę, kieruje Debora. To nie on jest prawdziwym bohaterem. Bez wątpienia, męscy wojownicy zostają zawstydzeni, tym bardziej że wojna jest postrzegana jako męska aktywność. Dla mężczyzn zawstydzające może być znalezienie się w nie-męskiej pozycji ${ }^{186}$.

${ }^{182}$ Zob. W. Groß, Richter, 284-286. Inaczej Baraka ocenia W. Hertzberg, Die Bücher Josua, Richter, Ruth, 176, według którego był odważnym, ale niepewnym misji człowiekiem.

${ }^{183} \mathrm{Wg}$ T.C. Butler, Judges, są oni obiektami satyry i kpiny ze strony narratora, nie ma w nich nic z heroizmu. Analiza literackokrytyczna w H.-D. Neef, „,Der Sieg Debora", 34-49, zwł. 48, prowadzi do wniosku, że w centrum opowiadania stoi zwycięstwo Baraka nad Siserą jako wypełnienie Bożego polecenia, choć Barak w odróżnieniu od Debory i Jael jest reagującą, a nie inicjującą osobą. Artykuł ten jest przykładem tego, jak pozornie obiektywizująca analiza literackokrytyczna najpewniej nieświadomie - skutkuje zatarciem genderowego skandalu opowiadania.

${ }^{184}$ Nawet jeśli formalnie wyrażone za pomocą impt. (w w. 19 z niejednoznacznym א্লT; zob. HAHAT; zaś w w. 20 impt. lub inf. cs.), to nie są to polecenia (zob. T.C. Butler, Judges), lecz prośby, co pokazuje zwrócenie się o „trochę wody” czy instrukcja, jak Jael ma postąpić, gdyby ktoś rozpytywał o niego, mimo że Jael ukryła go niejako podwójnie (w namiocie i pod przykryciem). Z tym związana jest też informacja o tym, że był on całkowicie wyczerpany (w. 21b).

185 Zob. M. Navarro Puerto, Księga Jozuego, Sędziów i Rut, 105; S. Järlemyr, „A Tale of Cross-Dressers”, 53. Wg W. Groß, Richter, 285, wchodzi coraz bardziej rolę ofiary.

186 Zob. G.A. Yee, „By the Hand of a Woman”, 115; S. Järlemyr, „A Tale of Cross-Dressers", 60-61. Może też obrazować pułapkę, jaką jest postrzeganie kulturowej męskości i kobiecości jako opozycji (zob. powyższe Wprowadzenie i przywołana tam literatura). 
O ile Sisera zachowuje się jak dziecko, o tyle Barak jak „kobieta” kierowana przez Deborę - prawdziwego „mężczyznę”.

W Pieśni Debory, która mogła być „źródłem” dla narratora, Barak jest wychwalany na równi z Deborą $(5,12-15)$. Opowiadanie przekształca jego rolę, czyniąc go antybohaterem czy słabą, ostatecznie nieliczącą się osobą ${ }^{187}$. W Pieśni pojawia się również matka Sisery (5,28-30), wyglądająca za powracającym z bitwy synem ${ }^{188}$. Opóźniający się powrót tłumaczy sobie, co podpowiadają jej też ,najmądrzejsze z księżniczek", tym, że łup - w szczególności kobiety, i to przypadające po dwie na każdego wojownika - opóźniają powrót. Okazuje się jednak, że Sisera znalazł pozornie matczyną opiekę u Jael, która go zabija. Jael jest swego rodzaju anty-matką Sisery. Debora i Jael nie stały się dwiema brankami wojennymi, które się gwałci ${ }^{189}$, lecz dwiema wojowniczkami, które sprawiają, że Sisera już nigdy nie powróci. Nie mężczyzna-dowódca wyznacza los kobietom, ale to kobiety naznaczyły jego los, jego koniec.

Jael jest żoną Kenity, a prowadzą oni półnomadyczne życie. Ponadto odłączyli się od Kenitów, są więc obcymi w okolicach Kedesz (w. 11). Dla żadnej ze stron nie mogli stanowić liczącego się faktora. Mimo to Jael staje się główną bohaterką i, uczestnicząc w ocaleniu Izraelitów ${ }^{190}$, zajmuje miejsce $\mathrm{w}$ historii Izraela - najpierw dzięki Pieśni Debory, a potem za sprawą narracji z Sdz $4{ }^{191}$. Uciskane plemiona izraelskie znajdowały się w opłakanej sytuacji, bezbronne w obliczu armii Sisery dysponującej rydwanami ${ }^{192}$. Jael wywodziła się z obcych Kenitów, a Debora z izraelskiego plemienia Issachara.

187 Zob. W. Groß, Richter, 296.

${ }^{188}$ Do paraleli i opozycji pomiędzy matką Sisery a Jael w Pieśni Debory zob. R.I. Thelle, „Matrices of motherhood in Judges 5”, 448-449.

189 S. Järlemyr, „A Tale of Cross-Dressers”, 57-58, wskazuje, że było to typowe działanie zwycięzców na starożytnym Bliskim Wschodzie, tak że role genderowe zostały tutaj całkowicie odwrócone.

190 T.J. Schneider, Judges, 58, zwraca uwagę na fakt, że nie-Izraelitka bierze udział w ocaleniu Izraela.

${ }^{191}$ Od zawsze budziła żywe zainteresowanie, co pokazuje też sztuka (zob. chociażby reprodukcje umieszczone w A. Scherer, „Sisera”).

192 T.C. Butler, Judges, zauważa, że w Sdz często podkreślane jest technologiczne zacofanie Izraelitów (Ehud posługuje się nożem, Szamgar ościeniem na woły). 
Zwyciężczynie nad wrogami i ośmieszające mężczyzn były niejako podwójnie poszkodowane: jako kobiety i jako obce czy należące do prześladowanych grup.

Bóg dokonał dzieła ocalenia dzięki kobietom ${ }^{193}$. Bitwa okazuje się brutalna, podobnie jak śmierć Sisery, co jednak nie zajmuje narratora. Opowiada on o dzielnych kobietach zmierzających prosto do celu i słabych, zagubionych mężczyznach. Bohaterowie wcale nie są marionetkami w Bożych rękach, mogą się sprzeciwić Bogu lub działać, wiedząc o tym lub nie, zgodnie z Bożymi zamiarami ${ }^{194}$. Tekst ukazuje różne postawy wobec Bożego działania, ale nie w oderwaniu od płci bohaterek/bohaterów. Aktywne, odważne i samodzielne są kobiety, które stają się współuczestniczkami w Bożym zbawieniu. Bóg nie działa sam, ale poprzez kobiety. W negatywnym świetle ukazany został zarówno Barak, który z oporami, oglądając się na kobietę, spełnia swoje zadanie, jak i główny wróg - Sisera - opisany jako słaby i dziecinny pomimo posiadania potężnego wojska. Kobiety są przykładem mądrego i posłusznego Bogu działania, roztropności, odwagi.

W opowiadaniu nie chodzi o przekazanie historycznych informacji o ważnej bitwie, ale jest ona pretekstem do snucia opowieści o istotnych dla odbiorców sprawach. Wprawdzie Bóg ujmuje się za swoim ludem i go wyzwala, ale na czoło wysuwają się tutaj działania kobiet przeciwstawione postawie mężczyzn. Narrator zmusza czytelnika do spojrzenia z politowaniem na słabych i przegranych mężczyzn: Sisera przegrywa bitwę i traci życie w hańbiący sposób, Barak sam sytuuje się w pozycji bojaźliwego narzędzia Debory i świadka bohaterstwa Jael. Na pierwszym planie stoją kobiety posłuszne Bogu, odważnie działające i prowadzące do wielkiego zwycięstwa. To im przypada chwała z pokonania wroga (w. 9a). Obie wykraczają poza społecznie narzucane role genderowe. To starożytne opowiadanie stoi w krytycznym dystansie do ról, w jakich kobiety najczęściej pojawiały się

${ }^{193}$ Wg G.A. Yee, „By the Hand of a Woman”, 114, jest to anomalia w porządku społecznym.

194 Zob. W. Groß, Richter, 286. 
według Starego Testamentu w dawnym izraelskim społeczeństwie ${ }^{195}$. Również dzisiaj taki krytyczny namysł wciąż wydaje się potrzebny.

\title{
Deborah and Jael opposite to Barak and Sisera: Gender Roles in Judges 4:1-24
}

\begin{abstract}
The story of Deborah in Judg 4 provokes a question about gender roles of the four main female and male characters. Although Deborah and Yael are shown in the traditional role of a wife, almost all their activities go beyond the gender roles which are attributed to women. They go into "masculine" social domains of activity: judiciary, commanding an army, and killing an enemy. They both act not only wisely, but also according to God's saving will. In contrast, masculine characters or heroes are exposed to ridicule and humiliated: they are put in "unmanly" roles as dependent, frightened, and in need of care. Finally, the male warrior Sisera is cunningly killed by a woman armed only with household objects. The story is a gender critique of roles attributed to both sexes, especially to women.
\end{abstract}

Keywords: Book of Judges 4, gender criticism, gender roles, Deborah, Jael, shame

\section{Bibliografia}

Assis, E., „The Hand of a Woman: Deborah and Yael (Judges 4)”, Journal of Hebrew Scriptures 5 (2007), Article 19, 1-12.

Assis, E., „Man, Woman and God in Judg 4”, Scandinavian Journal of the Old Testament 20 (2006) nr 1, 110-124.

Bae, H.-S., „Reconsidering Barak's response in Judges 4”, Biblica 98 (2017) nr 4, 504-519 (abstrakt).

[BHQ] Biblia Hebraica Quinta cum apparatu critico novis curis elaborato: שט / Judges, prepared by N. Fernández Marcos (The Masorah prepared in cooperation with D. Marcus), A. Schenker i in. (red.), Stuttgart 2010.

[BHS] Biblia Hebraica Stuttgartensia, wyd. 5. poprawione, K. Elliger, W. Rudolph, A. Schneker (red.), Stuttgart 1997.

Bledstein, A., „Is Judges a Woman's Satire of Men Who Play God?”, Vetus Testamentum 40 (1990) nr 2, 129-138.

Blum, E., „Notwendigkeit und Grenzen historischer Exegese. Plädoyer für eine alttestamentliche "Exegetik»", w: Theologie und Exegese des Alten Testaments/Hebräischen Bibel: Zwischenbilanz und Zukunftperspektiven (Stuttgarter Bibelstudien 200), B. Janowski (red.), Stuttgart 2005, 11-40.

Brenner, A., „A Triangle and a Rhombus in Narrative Structure: A Proposed Integrative Reading of Judges IV and V?", w: A. Brenner (red.), A Feminist

195 Zob J. Slawik, „O rolach kobiet w Starym Testamencie (Biblii Hebrajskiej)”, 9-30 i tenże, „Stary Testament świadectwem patriarchalnej kultury?”, 81-92. 
Companion to Judges (Feminist Companion to the Bible 4; series II), Sheffield 1993, 34-54.

Brockelmann, C., Hebräische Syntax, Neukirchen 1956.

Burzyńska, A., Markowski, M.P., Teorie literatury XX wieku: Podręcznik, Kraków 2007.

Butler, T.C., Judges (Word Biblical Commentary 8), Grand Rapids (MI) 2009 (wersja elektroniczna bez numerów stron i sekcji).

Calwer Bibellexikon, T. Schlatter (red.), wyd. 5., Stuttgart 1985.

Connel, R., Socjologia ptci: Pteć w ujęciu globalnym, Olga Siara (tłum.) (tyt. oryg. Gender in World Perspective, $2^{\text {nd }}$ edition), Warszawa 2013.

C.R. Stimpson, G.H. Herdt (red.), Critical terms for the study of gender, Chicago-London 2014.

Crüsemann, F., Die Tora. Theologie und Sozialgeschichte des alttestamentlichen Gesetzes, wyd. 2., Gütersloh 1997.

Dziadosz, D., Księga Sędziów rozdziały 1 - 5: Wstęp, przekład z oryginatu, komentarz (NKB.ST VII/1), Częstochowa 2019.

Eder, S., „Debora / Deboralied”, WiBiLex (Das wissenschaftliche Bibellexikon im Internet): https://www.bibelwissenschaft.de/stichwort/16245/ (permanentny link; dostęp 21.06.2020).

Eder, S., „Jabin”, WiBiLex (Das wissenschaftliche Bibellexikon im Internet): http://www.bibelwissenschaft.de/stichwort/22007/ (permanentny link; dostęp 21.06.2020).

Elgavish, D., „Ya'el, Wife of Heber the Kenite, in Biblical Perspective”, Jewish Law Association Studies 16 (2007), 78-100.

Finkelstein, I., Silberman, N.A., Keine Posaunen vor Jericho: Die archäologische Wahrheit über die Bibel, M. Magall (tłum.) (tyt. oryg. The Bibel Unearthed: Archaeology's New Vision of Ancient Israel and the Origin of Its Sacred Texts), wyd. 2., München 2005.

García Bachmann, M., Judges (Wisdom Commentary 7), Collegeville (MN) 2018.

Gesenius' Grammatik: Wilhelm Gesenius' Hebräische Grammatik, völlig umgearbeitet von E. Kautzsch, wyd. 28., Leipzig 1909. Wydanie w Gesenius-Kautzsch-Bergsträsser, Hebräische Grammatik, Hildsheim-Zürich-New York 1991.

Groß, W., Richter (Herders Theologischer Kommentar zum Alten Testament), Freiburg i.B.-Basel-Wien 2009.

[HAHAT] Gesenius, W., Hebräisches und Aramäisches Handwörterbuch über das Alte Testament, opr. i wyd. Herbert Donner, współpraca U. Rüterwörden, J. Jenz, rozpoczęcie D.R. Meyer, wyd. 18., Heidelberg-Dordrecht-London-New York 2013. 
[HAL] Kohler, L., Baumgartner, W., Hebräisches und aramäisches Lexikon zum Alten Testament, t. I-II, na nowo opracowany przez W. Baumgartner, J.J. Stamm i B. Hartmann, wyd. 3., Leiden-New York-Köln 1995.

Hentschel, G., „Das Buch der Richter”, w: Zenger E. i in., Einleitung in das Alte Testament, Kohlhammer Studienbücher Theologie 1,1, wyd. 7., Stuttgart 2008, 213-221.

Hertzberg, W., Die Bücher Josua, Richter, Ruth (Das Alte Testament Deutsch 9), 5. wyd. (niezmienione), Göttingen 1973.

Hossfeld, F.-L., Zenger, E., Psalmen 51-100 (Herders Theologischer Kommentar zum Alten Testament), wyd. 3., Freiburg-Basel-Wien 2000.

Jagiełło, J., Oko, D. (red.), Gender - spojrzenie krytyczne, Kielce 2016.

Janssen, C., „Gender (NT)”, WiBiLex (Das wissenschaftliche Bibellexikon im Internet): http://www.bibelwissenschaft.de/stichwort/48903/ (permanentny link; dostęp 21.06.2020).

Järlemyr, S., „A Tale of Cross-Dressers, Mothers, and Murderers: Gender and Power in Judges 4 and 5", Svensk Exegetisk Arsbok 81 (2016), 49-62.

Jasinski, M., „Prorokini Debora - «wskrzesicielka» nadziei Izraela. Studium egzegetyczno-teologiczne Sdz 4-5”, The Biblical Annals 7 (2017) nr 4, $415-439$.

Kimmel, M., Społeczeństwo genderowe, A. Czerniak, A.M. Kłonkowska (tłum.) (tyt. oryg. The Gendered Society), Gdańsk 2015.

Knauf, E.A., „Keniter”, WiBiLex (Das wissenschaftliche Bibellexikon im Internet): http://www.bibelwissenschaft.de/stichwort/23400/ (permanentny link; dostęp 21.06.2020).

Layton, S.C., „Ya'el in Judges 4: An Onomastic Rejoinder”, Zeitschrift für die alttestamentliche Wissenschaft 109 (1997), 93-94.

Mandolfo, C., „Women, Violence, and the Bible: The Story of Jael and Sisera as a Case Study", Biblical Interpretation 27 (2019), 340-353.

Mayfield, T., „The Accounts of Deborah (Judges 4-5) in Recent Research”, Currents in Biblical Research 7 (2009) nr 3, 306-335.

Meynet, R., Wprowadzenie do hebrajskiej retoryki biblijnej, T. Kot (tłum.) (tyt. oryg. Études de Rhetorique biblique), Kraków 2001.

Navarro Puerto, M., Księga Jozuego, Sędziów i Rut (Rozumieć Stary Testament: Komentarze duchowe), P. Rak (tłum.) (tyt. oryg. Los libros de Josue, Jueces y Rut), Kraków 1998.

Neef, H.-D., „Der Sieg Debora und Baraks über Sisera: Exegetische Beobachtungen zum Aufbau und Werden von Jdc 4, 1-24", Zeitschrift für die alttestamentliche Wissenschaft 101 (1989), 28-49.

Nissinen, M., Homoeroticism in the Biblical World. A Historical Perspective, K. Stjerna (tłum.) (tyt. oryg. Homoerotiikka Raamatun maailmassa), Minneapolis (MN) 1998. 
Noth, M., Das 2. Buch Mose: Exodus (Das Alte Testament Deutsch 5), wyd. 6. (niezmienione), Göttingen 1978.

Osborne, W.R., „A Biblical Reconstruction of the Prophetess Deborah in Judges 4", Journal for the Evangelical Study of the Old Testament 2 (2013) nr 2, 199-213.

Plöger, O., Sprüche Salomos (Proverbia) (BK.AT XVII), Neukirchen-Vluyn 1984.

Radkiewicz, M., „Co to są studia gender?”, Zadra (2013), http://pismozadra.pl/ component/content/article/109-zadra-2-3-2000/385-co-to-sa-studia-gender (dostęp 30.09.2020).

Sæbø, M., Sprüche (Das Alte Testament Deutsch 16,1), Göttingen 2012.

Scherer, A., „Jabin”, WibiLex: http://www.bibelwissenschaft.de/stichwort/22007/ (permanentny link; dostęp 21.06.2020).

Scherer, A., „Sisera”, WibiLex: http://www.bibelwissenschaft.de/stichwort/28946 (permanentny link; dostęp 21.06.2020).

Schmidt, W.H., Wprowadzenie do Starego Testamentu, P. Mathäus (tłum.) (tyt. oryg. Einführung in das Alte Testament, wyd. 5.), Bielsko-Biała 1997.

Slawik, J., Egzegeza Starego Testamentu: Wprowadzenie do metod egzegetycznych i podana tam literatura, Warszawa 2004.

Slawik, I., Slawik, J., „Homoseksualizm problemem Kościoła?”, Rocznik Teologiczny 52 (2010), 9-69.

Slawik, J., „O rolach kobiet w Starym Testamencie (Biblii Hebrajskiej)”, Rocznik Teologiczny 54 (2012), 9-30.

Slawik, J., „Stary Testament świadectwem patriarchalnej kultury?”, Scripta Biblica et Orientalia 4 (2012), 81-92.

Schneider, T.J., Judges: Studies in Hebrew Narrative and Poetry (Berit Olam), Collegeville (MN) 2000.

[THAT] Theologisches Handwörterbuch zum Alten Testament, tom I-II, E. Jenni, C. Westermann (red.), München-Zürich 1984.

Thelle, R.I., ,Matrices of motherhood in Judges 5”, Journal for the Study of the Old Testament 43 (2019) nr 3, 436-452.

Tov, E., Der Text der Hebräischen Bibel: Handbuch der Textkritik, StuttgartBerlin-Köln 1997.

[TWAT] Theologisches Wörterbuch zum Alten Testament, tom I-X, G.J. Botterweck, H. Ringgren, H.-J. Fabry (red.), Stuttgart-Berlin-Köln-Mainz 1973-2016.

Yee, G.A., „By the Hand of a Woman: The Metaphor of the Woman Warrior in Judges 4", Semeia 1993, 99-132.

Weisman, Z., „Charismatic Leaders in the Era of the Judges”, Zeitschrift für die alttestamentliche Wissenschaft 89 (1977), 399-411.

Witte, M., ,Geschichte / Geschichtsschreibung (AT)”, WiBiLex: https://www.bibelwissenschaft.de/stichwort/19400/ (permanentny link; dostęp 7.06.2020). 
Wolde, E. van, „Ya'el in Judges 4”, Zeitschrift für die alttestamentliche Wissenschaft 107 (1995), 240-246.

Wright, J.L., „Deborah's War Memorial: The Composition of Judges 4-5 and the Politics of War Commemoration", Zeitschrift für die alttestamentliche Wissenschaft 123 (2011), 516-534. 